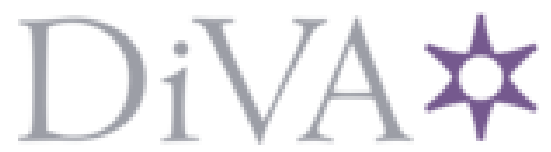

http://www.diva-portal.org

This is the published version of a paper published in Journal on Rehabilitation of Torture Victims and Prevention of Torture.

Citation for the original published paper (version of record):

Sigvardsdotter, E., Vaez, M., Rydholm Hedman, A-M., Saboonchi, F. (2016)

Prevalence of torture and other war-related traumatic events in forced migrants: A systematic review.

Journal on Rehabilitation of Torture Victims and Prevention of Torture, 26(2): 41-73

Access to the published version may require subscription.

N.B. When citing this work, cite the original published paper.

Permanent link to this version:

http://urn.kb.se/resolve?urn=urn:nbn:se:rkh:diva-2291 


\title{
Prevalence of torture and other war- related traumatic events in forced migrants: A systematic review
}

\author{
Erika Sigvardsdotter, PhD*, Marjan Vaez, PhD**, Ann-Marie Rydholm Hedman, PhD*, \\ Fredrik Saboonchi, Prof.*,**
}

\begin{abstract}
Aim: To describe and appraise the research literature reporting prevalence of torture and/or war-related potentially traumatic experiences (PTEs) in adult forced migrants living in high-income countries. Methods: A search for peer-reviewed articles in English was conducted in PubMed, Web of Science, PILOTS, key journals, and reference lists. Studies based on clinical samples and samples where less than half of participants were forced migrants were excluded. Data was extracted and a methodological quality appraisal was performed. Results: A total of 3,470 titles and abstracts were retrieved and screened. Of these, 198 were retrieved in full-text. Forty-one articles fulfilled inclusion criteria and the total number of study participants was 12,020 (median 170). A majority focused on specific ethnic groups or nationalities, Southeast Asian, Middle Eastern and Balkan being the most frequent. Reported prevalence rates of torture ranged between one and $76 \%$ (median $27 \%$ ).

Almost all participants across all studies had
\end{abstract}

\footnotetext{
*) The Swedish Red Cross University College, Stockholm, Sweden

$\left.{ }^{\star \star}\right)$ Division of Insurance Medicine, Department of Clinical Neuroscience, Karolinska Institute, Stockholm, Sweden

Correspondence to: erika.sigvardsdotter@rkh.se
}

experienced some kind of war-related PTE. Conclusions: Reported prevalence rates of torture and war-related PTEs vary between groups of forced migrants. Trauma history was often studied as a background variable in relation to mental health. The heterogeneity of data, as well as the methodological challenges in reaching forced migrants and defining and measuring traumatic experiences, prevent generalisation concerning trauma history across groups.

Keywords: forced migrants, migrants, refugees, war-trauma, torture

\section{Background}

Torture is the most severe violation of human rights a person can be subjected to. A wilful and intentional infliction of severe suffering or pain in another person, it destroys a person's identity, sense of self, and trust in other people. ${ }^{1}$ Torture, as defined by the UN, is "any act by which severe pain or suffering, whether physical or mental, is intentionally inflicted on a person ... by or at the instigation of or with the consent or acquiescence of a public official or other person acting in an official capacity ...". ${ }^{2}$ The World Medical Association (WMA) Tokyo declaration defines torture without specifying a perpetrator as "the deliberate, systematic or wanton infliction of physical or mental suffering by one or more persons 
acting alone or on the orders of any authority, to force another person to yield information, to make a confession, or for any other reason". ${ }^{3}$ The UN has established the Istanbul Protocol ${ }^{4}$ as a set of guidelines for the documentation of torture and its consequences.

Torture is practiced in over 140 countries worldwide according to Amnesty International, ${ }^{5}$ countries where many forced migrants in the world originate. The United Nations High Commissioner for Refugees (UNHCR) estimates that, as of the end of 2014, 59.5 million people were forcibly displaced by persecution, conflict or human rights violations. Of these, 14.4 million are refugees under the UNHCR's mandate, ${ }^{6}$ the remainder are either in refugee-like situations, displaced in their own country, in transit, seeking asylum in a foreign country, or rejected or "failed" asylum seekers.

Traumatic experiences, and torture in particular, have been found to be a predictor of mental ill-health, primarily posttraumatic stress disorder (PTSD), depression and/or anxiety. ${ }^{7}$ Because of its impact, trauma history is an important factor in the health of forced migrants.

Studies in other contexts than refuge and displacement have shown that approximately $25 \%$ of individuals subjected to a traumatic event develop PTSD. ${ }^{8}$ The majority of studies exploring this relationship have been carried out in relation to distinct events, like terror attacks ${ }^{9,10}$ or natural disasters, ${ }^{11-13}$ or as the result of combat experiences in veterans. ${ }^{14,} 15$ Many forced migrants have experienced multiple traumatic events, in some cases torture, and on-going hardship in their country of origin, during their flight, and post-migration. ${ }^{7,16}$ It has been argued that such situations cannot be compared to single, distinct events. ${ }^{8}$ Despite the large global population of forced migrants, research on trauma history, torture prevalence and their sequelae in this group is relatively rare. ${ }^{7,16-18}$

Earlier reviews of literature which report on trauma history have mainly focused on mental health, rather than the background variable, traumatic experiences. ${ }^{7,16,18}$ When these have included studies based on clinical samples, where the prevalence of trauma history can be expected to be elevated, or where traumatic experiences may be an inclusion criteria, high prevalence rates of violence and torture are artifacts of study design. ${ }^{16}$

Selective citation of figures concerning trauma history in forced migrants can serve different interests and give rise to either insufficient interventions or to stigmatisation and inappropriate assumptions of the level of traumatisation in these groups. It is therefore important to provide a comprehensive review focused on the trauma history prevalence rates in forced migrants.

The aim of the review was to describe and appraise the research literature reporting prevalence of torture and/or war-related potentially traumatic experiences (PTEs) in adult forced migrants living in high-income countries.

\section{Methods}

A systematic review of the literature of empirically based original studies reporting on prevalence of trauma history in the form of torture and/or war-related PTEs in forced migrants in high-income countries was performed. The PRISMA guidelines were followed where applicable. Searches of databases PubMed, Web of Science and PILOTS were conducted in February 2015, with a follow up search at the end of September 2015, combining the following search terms: (immigrant ${ }^{\star} \mathrm{OR}$ migrant ${ }^{\star} \mathrm{OR}$ refugee $^{\star}$ OR asylum seeker ${ }^{\star}$ ) AND (torture ${ }^{\star}$ 
OR traumatised ${ }^{\star} \mathrm{OR}$ war-trauma ${ }^{\star} \mathrm{OR}$ "political violence ${ }^{\star}$ " OR “organised violence ${ }^{\star}$ ” OR “posttraumatic stress $\star$ ” OR PTSD), including variants of spelling and hyphenation. Organised and political violence were included in order to reach a wider spectrum of human rights violations beyond war or torture. Posttraumatic stress (PTS) and PTSD were included as studies with this focus often report prevalence of related traumata. Where applicable, free-text search terms were used in combination with $\mathrm{MeSH}$ terms for optimum search criteria. ${ }^{19}$ Searches were restricted to peer-reviewed material where possible. Manual searches of bibliographies and relevant journals were performed. The results of the systematic search can be seen in Figure 1 on page 45 .

\section{Inclusion and exclusion criteria}

Eligible studies reported original empirical, quantitative data on the prevalence of torture or war-related PTEs among adult forced migrants in high-income countries. Studies had to be peer reviewed and written in English. No limit concerning date of publication was used. Where several articles reported on the same empirical material, one article - that which reported trauma history most thoroughly - was included.

Types of traumatic events: All definitions of torture were included, as was secondary torture, defined as having a family member, or in some cases a close friend, who has been subjected to torture. The fourth edition of the Diagnostic and Statistical Manual of Mental Disorders (DSM IV) criterion A1 of PTSD was used to define PTE in this study so that a greater variety of definitions would be included (rather than the more specific definitions in DSMV). This sets out that there has been exposure to a PTE when a person has "experienced, witnessed, or was confronted with an event or events that involved actual or threatened death or serious injury, or a threat to the physical integrity of self or others". ${ }^{20}$ For PTEs to be war-related, they should be expressly linked to conflict, persecution, or other human rights violations. Torture and war-related PTEs are jointly referred to as trauma history. Studies reporting only on general pre-migration harm, or exclusively reporting trauma history unrelated to war or persecution, such as robbery or natural disasters, were excluded.

Types of study samples: The target population for this review - forced migrants - was taken to include refugees, quota refugees, internally displaced persons (IDPs), persons under temporary protection, asylum seekers and failed asylum seekers. Studies where less than half of the respondents were forced migrants, or where it was impossible to determine whether they were forced or voluntary migrants, were excluded. Studies based on samples recruited from treatment centres for torture survivors, among psychiatric (in- or out-) patients, or where any previous experience of trauma or loss was an inclusion criteria, where excluded. Samples recruited among primary care patients were included.

Studies concerned with forcibly displaced children or adolescents were excluded. Age span and distribution were sometimes difficult to determine, and individual assessments were made, the guiding principle being that all participants should be adult or close to adulthood. The minimum age differed between studies, some used a minimum age of 18 , some of 16 ; these were all included. For example, one study recruited participants in a Danish high school, where $85 \%$ of participants where between 17 and 20 years old (mean age 18.5, SD 2.1). The view was taken that all 
respondents were close to adulthood, and the study was included. ${ }^{21}$ Studies where the age distribution was unclear were excluded. ${ }^{22,23}$ Where age-specific data was available, only data for adult respondents was extracted. ${ }^{24}$

Studies with 50 or less respondents (relevant to this review) were also excluded.

Types of contexts: High-income countries were defined as the members of the Organisation for Economic Co-operation and Development (OECD). Studies concerning Holocaust survivors, or refugees from East to West Germany during the cold war were excluded.

\section{Data extraction and quality assessment}

Extracted data from the included articles comprised: aim, year and country of study, nationality/ethnicity and legal status of the participants, details on study design (design, sampling method, size and recruitment context of sample, response rate, number of participants), type of measure, instrument used to record trauma history, and number of trauma items. The statistics extracted were prevalence of torture, witnessed torture and secondary torture. Prevalence rates of the three most common war-related PTE-items reported were also extracted, as well as the mean number of trauma, where reported. Lack of food, water, shelter and medical care were common across studies, but were not extracted among trauma history items. Where war-related PTEs were reported in a single item, the prevalence rate and the question were recorded.

A quality appraisal of all included articles was performed, based on a modified version of standardised published guidelines for quality assessment of prevalence data. ${ }^{25}$ The chosen assessment checklist has been used in systematic reviews of descriptive statistics concerning prevalence of reported events. ${ }^{26}$ The checklist was modified to specifically evaluate the quality of the descriptive data on prevalence of trauma history, rather than the entire analyses. Questions regarding whether a definition of torture had been used, whether standard translation or interpretation procedures were followed, and whether the studies had ethical approval were added. Items concerning validation or reliability were removed, as the included articles did not generally specify validity beyond symptom instruments and not for trauma history items. Questions concerning analysis and reporting of confidence intervals were deemed irrelevant and removed. Instead, a question concerning stratified reporting of prevalence rates was included.

\section{Results}

The systematic search resulted in 3469 titles, and one additional title was found in the manual search. Of these, 1075 titles were removed as duplicates and another 2195 were removed after screening of the title and abstract; 198 articles were retrieved in full text. The final selection consisted of 41 articles meeting the criteria for inclusion, a list of which can be found in Appendix A with all of the characteristics and findings of each study.

Of the selected articles, 17 included prevalence, frequency or amount, of trauma history among their objectives. The remaining 24 reported trauma history as a background factor or control variable in an analysis of mental health, or in the context of validity tests or factor analysis. Thirty three articles specifically reported on prevalence of torture or witnessing torture, five of which reported no other types of pre-migration PTEs.

An aspect of mental health was the primary object of all articles but two. ${ }^{27,28}$ Thirty-six articles reported prevalence of mental illness in forced migrants. Most 
Figure 1: Results of systematic search

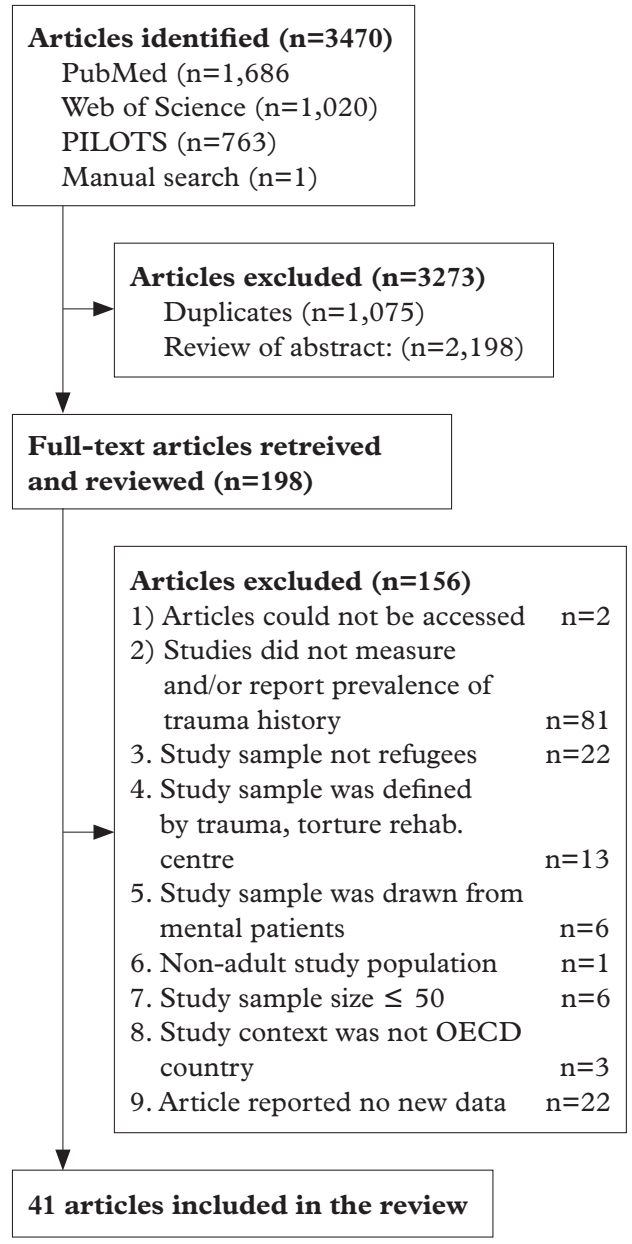

common, in 31 cases, PTSD was either screened for or diagnosed. Other diagnoses or screening concerned major depression (MD), depressive symptoms, anxiety, and psychological distress, often in combination with PTSD and/or each other. One article reported validity for a PTSD-screening instrument, ${ }^{29}$ another reported on validity of self-reported experience of torture, ${ }^{28}$ and one on a principal components analysis of trauma history items. ${ }^{27}$

\section{Study characteristics}

Among those who reported year of data collection, one was carried out in the 80 's, ${ }^{30}$ eight in the 90 's, 16 between 2000 and 2010, and six since 2010.31-36 Approximately half (20 articles) reported approval from an ethical board or committee. The countries producing the largest number of studies were USA (9) and Australia (8), followed by Sweden and Denmark (4), and Canada and Switzerland (3). The most common approach was to target certain ethnic groups or nationalities. South East Asian and Middle Eastern origins were the most common, followed by the Balkans. The distribution of ethnicities/nationalities of the respondents can be found in Table 1 .

Table 1: Origin of study participants in the articles included in this review. In parenthesis, the origin/ethnicity of the study participants as described in the articles.

\begin{tabular}{lc}
\hline Origin & $\begin{array}{c}\text { No. of } \\
\text { studies }\end{array}$ \\
\hline $\begin{array}{l}\text { Asian } \\
\text { (Afghan, Burmese, Cambodian, }\end{array}$ & 9 \\
$\begin{array}{l}\text { Karen, Tamil, Vietnamese) } \\
\text { Middle Eastern } \\
\text { (Arab, Mandaean, Iraqi, Iranian, }\end{array}$ & 8 \\
$\begin{array}{l}\text { Kurdish, Turkish, Syrian, Middle } \\
\text { Eastern) }\end{array}$ & \\
$\begin{array}{l}\text { Balkan } \\
\text { (Bosnian, Kosovar, Kosovo-Albanian) }\end{array}$ & 8 \\
$\begin{array}{l}\text { African } \\
\text { (Somali, Somali/Oromo, Sudanese) }\end{array}$ & 3 \\
$\begin{array}{l}\text { Latin American } \\
\text { (Guatemalan, Latin American) }\end{array}$ & 2 \\
$\begin{array}{l}\text { Various } \\
\text { (Asylum seekers, quota refugees, }\end{array}$ & 11 \\
$\begin{array}{l}\text { Latin American + Turkish and } \\
\text { Iranian, Latin American + African) }\end{array}$ & \\
\hline
\end{tabular}


Regarding the legal status of respondents, 25 articles were concerned with refugees, eight with asylum seekers, one with rejected asylum seekers, ${ }^{37}$ and one with quota refugees. ${ }^{34}$ Five studies engaged in comparing different migrant groups: voluntary migrants, asylum seekers and refugees, ${ }^{38}$ detained and non-detained, ${ }^{33}$ newly arrived and less newly arrived asylum seekers, ${ }^{39}$ and persons with temporary or permanent protection visas. ${ }^{40}$

\section{Methodology}

Of the included articles, 39 were cross-sectional studies and the remaining two were part of longitudinal studies. ${ }^{41,42}$ The total number of study participants in the included studies was 12,020 , with an average and median of 289 and 179 participants respectively.

Sampling: The majority of studies were based on convenience/mixed (17) or consecutive/ total (15) samples. They were recruited in various contexts - at refugee resettlement agencies, detention centres, community services, asylum centres, refugee health, or reception centres or NGOs. Recruiting was often done by community experts or by bilingual caseworkers.

Some studies made use of the fact that, in several countries, asylum seekers and refugees are recommended, or obliged, to attend a health screen. Information was either extracted directly from medical records ${ }^{24}$ or questionnaires or interviews were performed in connection with the health screen, ${ }^{31,34,43}$ or registers from refugee health screens were used as a sampling frame. ${ }^{44}$

Nine studies were based on random samples. In two of these, the researchers had been able to use data from, or participate in projects where large-scale household surveys were carried out. ${ }^{45,46}$ The remaining six should not be understood as fully probabilistic samples, but rather that the researchers used some element of randomness in the sampling process. A typical example is Sabin et al. ${ }^{47}$ who studied trauma history and general and mental health among Guatemalan refugees living in refugee camps in Chiapas, Mexico. For security and practical reasons, they had to make a convenience sample of the refugee camps - several were considered impossible or unsafe to visit. In the five chosen refugee camps, they were able to interview one randomly chosen adult per household.

A study by Marshall et al. ${ }^{48}$ illustrates the challenges of producing a sampling frame, in their study of Cambodian refugees in Long Beach, California. They made a sampling frame by letting a community expert survey randomly selected census blocks (stage one) in four areas known to include a large Cambodian population. The community expert selected households likely to contain Cambodian individuals, relying on visual signs, such as plants favoured by the Cambodian community or Buddhist or other icons. A stratified random sample where households selected by the community expert were over-sampled was made (stage two). The final stage was to randomly select one individual per eligible household to be included in the survey (stage three).

\section{Instruments and procedures: The most} common instrument was the Harvard Trauma Questionnaire (HTQ), used in 15 studies. Around half of these indicated that they had modified the questionnaire, either taking away items that may offend, and/or adding items specific for the target group, often after taking counsel from focus groups or key-persons in the community. Other instruments used were the Traumatic Life 
Events Questionnaire (TLEQ), ${ }^{49,50}$ the Post-traumatic Diagnostic Scale (PDS) part $1,{ }^{29,51}$ the Communal Traumatic Events Inventory (CTEI), ${ }^{52}$ the Life Events and Social History Interview Schedule, ${ }^{53}$ the Stressful Life Events Screening Questionnaire, ${ }^{32}$ the War Trauma Questionnaire (WTQ), ${ }^{54}$ and the War Trauma Scale. ${ }^{44}$

Semi-structured interviews were used in three studies, ${ }^{30,55,56}$ structured interviews, without a pre-defined instrument in seven studies. A couple of studies used medical records, either from a refugee health care centre, ${ }^{30}$ or records from introductory medical examinations for refugees. ${ }^{24}$

Most studies focusing on specific nationalities or ethnic groups relied on established translation-back translation procedures, while the studies including asylum seekers or refugees of various origins to a greater extent used interpreters.

\section{Definitions of torture}

Of the 33 articles reporting prevalence of torture, only eight articles indicated that an official definition of torture was operationalised. The most common definition used was

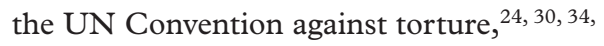

57,58 one of which also made use of the Istanbul Protocol to identify and record victims of torture. ${ }^{58}$ The WMA Tokyo protocol was used in two of the cases, ${ }^{28,59}$ and the US legal definition was used in one case. ${ }^{31}$ It is possible that other studies used a torture definition without reporting it.

Few expand on how the operationalization of the definitions was carried out. Two studies coded the responses in semi-structured interviews as either fulfilling the UN definition of torture or not. ${ }^{30,58}$ Jaranson et al. had their interviewers clarify to the respondents the context and nature of torture before asking a $/ \mathrm{N}$ question. ${ }^{57}$ Shannon et al. also asked $\mathrm{Y} / \mathrm{N}$ questions, and after positive responses to questions concerning exposure to torture, asked further questions "to determine if the torture caused severe physical or psychological suffering and who perpetrated the torture". ${ }^{31}$

\section{Prevalence rates of torture}

The overall prevalence rates of torture in the included studies varied between 1 and $76 \%$ (median 27\%). The first (Q1) and third quartile (Q3) being 18 and $40 \%$, respectively (see Table 2).

Table 2: Key counts and figures for torture prevalence in included studies ${ }^{i}$

\begin{tabular}{lrrr}
\hline & Torture (\%) & $\begin{array}{r}\text { Witnessing } \\
\text { torture (\%) }\end{array}$ & $\begin{array}{r}\text { Secondary } \\
\text { torture (\%) }\end{array}$ \\
\hline Number of groups & 33 & 8 & 10 \\
Min & 1 & 12 & 13 \\
Q1 & 18 & 32 & 26.25 \\
Median & 27 & 38.5 & 39 \\
Q3 & 40 & 42.75 & 45.75 \\
Max & 76 & 46 & 51 \\
\hline
\end{tabular}

${ }^{i}$ some studies include more than one study group and, in this count, subgroups in the articles were counted and accounted for separately. 
The lowest estimate of torture prevalence, $1 \%$, was found in a random sample of long-time resident Vietnamese immigrants to Australia, of which $57 \%$ were confirmed refugees. ${ }^{66}$ The item torture in this study also incorporated "being a victim of terrorists". Trauma history prevalence levels in this study were also generally lower than in other studies. The second and third lowest estimates of torture prevalence were $8 \%$ in a convenience sample of Mandaean refugees in Australia ${ }^{36}$ and $10 \%$ in a random sample of Syrian refugees living in a refugee camp in Turkey. ${ }^{32}$

The highest estimate, $76 \%$, was found among a convenience sample of Iranian and Turkish asylum seekers and refugees in the Netherlands in the late 1980's. Part of the sample was visitors to the medical centre, but they were in the minority. The second and third highest estimates were $67 \%$ in a convenience sample of Afghan asylum seekers in Japan ${ }^{62}$ and $54 \%$ in a random sample of Cambodian refugees in the US, ${ }^{48}$ respectively.

Torture prevalence rates reported separately for men and women, different age groups or nationalities were uncommon. Those who did found primary torture to be more common among men, ${ }^{24,30,34,43}$ and among older age groups or groups fleeing at a higher age. ${ }^{54,66}$ Secondary torture was found to be more common among women than men. ${ }^{24}$ There are, however, exceptions. Jaranson et al. ${ }^{57}$ noted a history of torture prevalence rate of $36 \%$ in a sample of Somali and Oromo refugees in Minnesota. When stratifying only for gender, the numbers were very similar, $45 \%$ of men and $43 \%$ of women had been tortured. But, when stratifying also for ethnicity, it emerged that in the Oromo group $69 \%$ of men and $17 \%$ of women had been tortured, and in the Somali group, $25 \%$ of men and $47 \%$ of women had been subjected to torture.

Hondius et al. ${ }^{30}$ reported that most of the respondents subjected to torture had also experienced other types of violent persecution. Another study found that torture survivors averaged 13 more traumatic events than non-tortured participants. ${ }^{57}$

Table 3: Reported torture methods, $n$ (\%), among tortured respondents in four studies

\begin{tabular}{|c|c|c|c|c|}
\hline Torture methods & $\begin{array}{l}\text { Masmas et } \\
\text { al. }{ }^{58}(n=64)\end{array}$ & $\begin{array}{l}\text { Montgomery } \\
\text { and Fold- } \\
\text { spang }{ }^{28} \\
(n=22)\end{array}$ & $\begin{array}{l}\text { Hondius et } \\
\text { al. }{ }^{30} \text { Study I } \\
(n=210)\end{array}$ & $\begin{array}{l}\text { Hondius et } \\
\text { al. }{ }^{30} \text { Study II } \\
(n=118)\end{array}$ \\
\hline $\begin{array}{l}\text { Unsystematic blows, incl. with } \\
\text { object / Beating or kicking }\end{array}$ & $58(91)$ & $19(86)$ & $187(89)$ & $92(78)$ \\
\hline Falanga & $25(40)$ & & $81(39)$ & $42(36)$ \\
\hline Suspension / Hanging & $19(30)$ & $6(27)$ & $59(28)$ & $30(25)$ \\
\hline Electric torture & $16(25)$ & $3(14)$ & $116(55)$ & $33(28)$ \\
\hline $\begin{array}{l}\text { Personal threats or threats to } \\
\text { family / Threats }\end{array}$ & $56(88)$ & $18(82)$ & $85(40)$ & $86(73)$ \\
\hline Witnessing torture & $40(63)$ & $13(59)$ & $56(27)$ & $52(44)$ \\
\hline Mock execution & $18(29)$ & & $22(10)$ & $27(23)$ \\
\hline Sexual abuse & $6(10)$ & & $26(12)$ & $26(22)$ \\
\hline
\end{tabular}




\section{Types of torture}

The types of torture reported are set out for each study as far as possible in Appendix A. Of particular interest are three articles which report on four studies where the prevalence of different types of torture are reported for three groups: Middle Eastern refugees in Denmark where $30 \%$ reported torture, ${ }^{28}$ asylum seekers from various countries in Denmark in 2007 where $45 \%$ reported some form of torture; ${ }^{58}$ and refugees and asylum seekers from Latin America, Turkey and the Middle East (study I) and from Turkey and Iran (study II) in the Netherlands in the late 1980's where $44 \%$ and $76 \%$ respectively reported some form of torture. ${ }^{30}$ More detailed statistics can be found in Table 3 .

\section{Measurement of torture and war-related PTEs}

As already mentioned, the measurement and reporting of war-related PTEs varies greatly between studies, as can be seen in Appendix A, which limits the possibility for comparison. The instruments used to record trauma history included both specific items, like "torture" and "seeing dead bodies", "murder of family or friend", and less specific items like "being close to death" and "combat situation", as well as open items such as "anything else". In semi-structured interviews or structured interviews with few trauma items, the reported war-related PTEs were much more general. One study found that the single question measuring war-related PTEs was endorsed by such a large share of respondents that statistical analysis of the sequelae of pre-migration trauma became difficult. $^{31}$

It is notable that several of the studies using multiple item instruments did not include any question about experiencing rape or sexual abuse..$^{27,54-56}$ One study found that traumatic events were more likely to be reported to health care personnel when a professional interpreter was present. ${ }^{61}$

\section{Prevalence rates of war-related PTEs}

Several studies report that all, ${ }^{47,48}$ or almost all $29,32,33,41,52,54,56$ of their study participants have experience of at least one traumatic event. The items "lack of food", "lack of water", "lack of shelter", "lack of medicine", and "living in a refugee camp" were included in many item-lists, and were often the most commonly reported; in a number of cases over 70 or $80 \%$ of respondents reported these items. ${ }^{27,35}$ Although unquestionably war-related, they are more relevant as context items.

The violent war-related PTEs most commonly reported were "being close to death", "unnatural death of a loved one", "being or living in a situation of war", "bombing or shooting", "combat situation", "imprisonment", "forced separation from family", "witnessing acts of violence" (see Appendix A). Items concerning rape and sexual abuse receive low rates across all studies, generally between 0 and $10 \% .32,38$ With few exceptions, ${ }^{30,52,56}$ studies do not report on flight-related PTEs.

As mentioned, 15 studies measured pre-migration trauma history with the HTQ Part 1 , albeit many with modifications, allowing for comparison of the results from 11 studies, as set out in Table 4 . 
Table 4: Trauma checklist scores from the 11 studies which used HTQ Part 1.

\begin{tabular}{|c|c|c|c|c|c|c|c|c|c|c|c|}
\hline 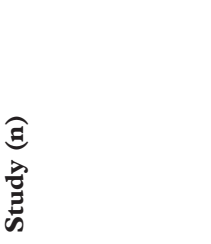 & 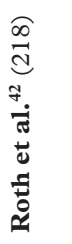 & 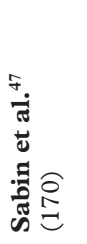 & 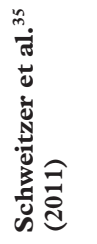 & 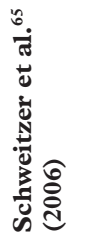 & 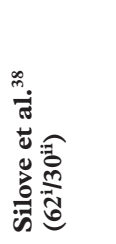 & 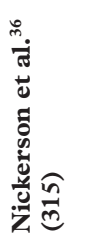 & 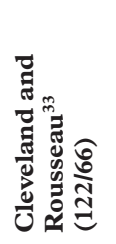 & 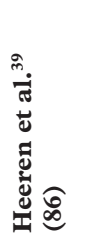 & 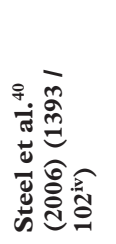 & 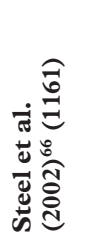 & 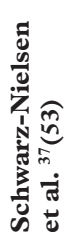 \\
\hline $\begin{array}{l}\text { Lack of food or } \\
\text { water }\end{array}$ & $\begin{array}{l}147 \\
(75)\end{array}$ & $\begin{array}{l}160 \\
(94)^{\mathrm{iv} /} \\
146 \\
(86)^{\mathrm{vi}}\end{array}$ & $\begin{array}{l}50 \\
(74)\end{array}$ & $\begin{array}{l}37 \\
(59)\end{array}$ & $\begin{array}{l}20(32) \\
/ 8(27)\end{array}$ & $\begin{array}{l}134 \\
(43)\end{array}$ & $\begin{array}{l}55(45) \\
/ 27(41)\end{array}$ & $33(38)$ & $\begin{array}{l}65(46) \\
/ 23(23)\end{array}$ & $\begin{array}{l}231 \\
(20)\end{array}$ & $\begin{array}{l}34 \\
(64)\end{array}$ \\
\hline $\begin{array}{l}\text { Ill without access } \\
\text { to medical care }\end{array}$ & $\begin{array}{l}108 \\
(57)\end{array}$ & & $\begin{array}{l}38 \\
(56)\end{array}$ & $\begin{array}{l}12 \\
(19)\end{array}$ & $\begin{array}{l}25(40) \\
/ 10(33)\end{array}$ & $\begin{array}{l}88 \\
(28)\end{array}$ & $\begin{array}{l}49(40) \\
/ 27(41)\end{array}$ & $22(26)$ & $\begin{array}{l}53(38) \\
/ 16(16)\end{array}$ & $43(4)$ & $\begin{array}{l}38 \\
(72)\end{array}$ \\
\hline Lack of shelter & $\begin{array}{l}146 \\
(74)\end{array}$ & $\begin{array}{l}145 \\
(85)\end{array}$ & $\begin{array}{l}47 \\
(69)\end{array}$ & $\begin{array}{l}36 \\
(57)\end{array}$ & $\begin{array}{l}19(31) \\
/ 9(30)\end{array}$ & $\begin{array}{l}85 \\
(27)\end{array}$ & $\begin{array}{l}38(31) \\
/ 16(24)\end{array}$ & $29(34)$ & $\begin{array}{l}26(19) \\
/ 11(11)\end{array}$ & $33(3)$ & $\begin{array}{l}26 \\
(49)\end{array}$ \\
\hline Imprison-ment & $\begin{array}{l}19 \\
(10)\end{array}$ & $12(7)$ & $\begin{array}{l}13 \\
(19)\end{array}$ & $\begin{array}{l}17 \\
(27)\end{array}$ & $\begin{array}{l}12(19) \\
15(17)\end{array}$ & $\begin{array}{l}59 \\
(19)\end{array}$ & $\begin{array}{l}39(32) \\
/ 14(21)\end{array}$ & $24(28)$ & $\begin{array}{l}52(37) \\
/ 15(15)\end{array}$ & $\begin{array}{l}146 \\
(13)\end{array}$ & $\begin{array}{l}18 \\
(34)\end{array}$ \\
\hline Serious injury & $\begin{array}{l}38 \\
(20)\end{array}$ & $\begin{array}{l}21 \\
(12)\end{array}$ & $\begin{array}{l}19 \\
(28)\end{array}$ & $8(13)$ & $\begin{array}{l}8(13) \\
/ 4(13)\end{array}$ & $\begin{array}{l}31 \\
(10)\end{array}$ & $\begin{array}{l}47(39) \\
/ 23(35)\end{array}$ & $16(19)$ & $\begin{array}{l}20(14) \\
/ 9(9)\end{array}$ & $97(8)$ & $\begin{array}{l}22 \\
(42)\end{array}$ \\
\hline $\begin{array}{l}\text { Combat } \\
\text { situation }\end{array}$ & $\begin{array}{l}180 \\
(91)\end{array}$ & $\begin{array}{l}34 \\
(20)^{\mathrm{vii}}\end{array}$ & $\begin{array}{l}38 \\
(58)\end{array}$ & $\begin{array}{l}24 \\
(38)\end{array}$ & $\begin{array}{l}14(23) / \\
3(10)\end{array}$ & $\begin{array}{l}53 \\
(17)\end{array}$ & $\begin{array}{l}33(27) \\
/ 26(39)\end{array}$ & $25(29)$ & $\begin{array}{l}21(15) \\
/ 8(8)\end{array}$ & $73(6)$ & $\begin{array}{l}31 \\
(59)\end{array}$ \\
\hline Brain-washing & $\begin{array}{l}39 \\
(23)\end{array}$ & $\begin{array}{l}86 \\
(51)\end{array}$ & $\begin{array}{l}19 \\
(28)\end{array}$ & $\begin{array}{l}10 \\
(16)\end{array}$ & $\begin{array}{l}7(11) \\
/ 5(17)\end{array}$ & $14(4)$ & & $9(10)$ & $\begin{array}{l}18(13) \\
/ 6(6)\end{array}$ & & $\begin{array}{l}12 \\
(23)\end{array}$ \\
\hline $\begin{array}{l}\text { Rape or sexual } \\
\text { abuse }\end{array}$ & $8(4)$ & $6(4)$ & $7(10)$ & $7(11)$ & $\begin{array}{l}0(0) \\
/ 0(0)\end{array}$ & $9(3)$ & $\begin{array}{l}24(20) \\
/ 19(29)\end{array}$ & $\begin{array}{l}9(10) \\
\text { viii/ } 4(5) \\
\text { iv }\end{array}$ & & $\begin{array}{l}8(1)^{\mathrm{x}} \\
/ 4(0)^{\mathrm{xi}}\end{array}$ & $\begin{array}{l}12 \\
(23)\end{array}$ \\
\hline $\begin{array}{l}\text { Forced isolation } \\
\text { from others }\end{array}$ & $\begin{array}{l}66 \\
(35)\end{array}$ & & $\begin{array}{l}11 \\
(16)\end{array}$ & $\begin{array}{l}14 \\
(22)\end{array}$ & $\begin{array}{l}17(27) \\
/ 6(20)\end{array}$ & $\begin{array}{l}32 \\
(10)\end{array}$ & $\begin{array}{l}53(43) \\
/ 19(29)\end{array}$ & $27(31)$ & $\begin{array}{l}20(14) \\
/ 6(6)\end{array}$ & $28(2)$ & $\begin{array}{l}27 \\
(51)\end{array}$ \\
\hline $\begin{array}{l}\text { Being close to } \\
\text { death }\end{array}$ & $\begin{array}{l}112 \\
(61)\end{array}$ & $\begin{array}{l}95 \\
(56)\end{array}$ & $\begin{array}{l}28 \\
(41)\end{array}$ & $\begin{array}{l}19 \\
(30)\end{array}$ & $\begin{array}{l}25(40) \\
/ 10(33)\end{array}$ & $\begin{array}{l}156 \\
(50)\end{array}$ & $\begin{array}{l}110(90) \\
/ 61(92)\end{array}$ & $34(40)$ & $\begin{array}{l}106(76) \\
/ 29(29)\end{array}$ & $\begin{array}{l}167 \\
(14)\end{array}$ & $\begin{array}{l}34 \\
(64)\end{array}$ \\
\hline $\begin{array}{l}\text { Forced } \\
\text { separation from } \\
\text { family }\end{array}$ & $\begin{array}{l}86 \\
(45)\end{array}$ & $\begin{array}{l}79 \\
(47)\end{array}$ & $\begin{array}{l}31 \\
(46)\end{array}$ & $\begin{array}{l}54 \\
(86)\end{array}$ & $\begin{array}{l}29(46) \\
/ 14(47)\end{array}$ & $\begin{array}{l}43 \\
(14)\end{array}$ & $\begin{array}{l}79(65) \\
/ 45(68)\end{array}$ & $37(44)$ & $\begin{array}{l}36(26) \\
/ 11(11)\end{array}$ & $\begin{array}{l}129 \\
(11)\end{array}$ & $\begin{array}{l}32 \\
(60)\end{array}$ \\
\hline $\begin{array}{l}\text { Murder of family } \\
\text { or friend }\end{array}$ & $\begin{array}{l}94 \\
(48)\end{array}$ & $\begin{array}{l}90 \\
(53)\end{array}$ & $\begin{array}{l}23 \\
(34)\end{array}$ & $\begin{array}{l}43 \\
(68)\end{array}$ & $\begin{array}{l}24(39) \\
/ 14(46)\end{array}$ & $\begin{array}{l}123 \\
(39)\end{array}$ & $\begin{array}{l}56(46) \\
135(53)\end{array}$ & $29(34)$ & $\begin{array}{l}105(75) \\
/ 62(61)\end{array}$ & $38(3)$ & $\begin{array}{l}32 \\
(60)\end{array}$ \\
\hline $\begin{array}{l}\text { Unnatural death } \\
\text { of family or } \\
\text { friend }\end{array}$ & $\begin{array}{l}85 \\
(45)\end{array}$ & $\begin{array}{l}76 \\
(45)\end{array}$ & $\begin{array}{l}29 \\
(43)\end{array}$ & $\begin{array}{l}11 \\
(18)\end{array}$ & $\begin{array}{l}29(47) \\
/ 16(53)\end{array}$ & $\begin{array}{l}130 \\
(41)\end{array}$ & $\begin{array}{l}54(44) \\
135(53)\end{array}$ & $35(41)$ & $\begin{array}{l}110(79) \\
/ 63(62)\end{array}$ & & $\begin{array}{l}36 \\
(68)\end{array}$ \\
\hline $\begin{array}{l}\text { Murder of } \\
\text { stranger/s }\end{array}$ & $\begin{array}{l}85 \\
(44)\end{array}$ & $\begin{array}{l}75 \\
(44)\end{array}$ & $\begin{array}{l}13 \\
(19)\end{array}$ & $\begin{array}{l}11 \\
(18)\end{array}$ & $\begin{array}{l}29(46) \\
/ 12(40)\end{array}$ & $\begin{array}{l}77 \\
(24)\end{array}$ & $\begin{array}{l}52(43) \\
/ 24(36)\end{array}$ & $17(20)$ & $\begin{array}{l}68(49) \\
132(32)\end{array}$ & & $\begin{array}{l}28 \\
(53)\end{array}$ \\
\hline $\begin{array}{l}\text { Lost or } \\
\text { kidnapped }\end{array}$ & $\begin{array}{l}53 \\
(28)\end{array}$ & $\begin{array}{l}36 \\
(21)\end{array}$ & $9(13)$ & $8(13)$ & $\begin{array}{l}8(13) \\
/ 6(20)\end{array}$ & $\begin{array}{l}30 \\
(10)\end{array}$ & $\begin{array}{l}28(23) \\
/ 11(17)\end{array}$ & $15(17)$ & $\begin{array}{l}16(11) \\
/ 6(6)\end{array}$ & & $\begin{array}{l}26 \\
(42)\end{array}$ \\
\hline Torture & $\begin{array}{l}90 \\
(53)\end{array}$ & $\begin{array}{l}24 \\
(14)\end{array}$ & $\begin{array}{l}20 \\
(30)\end{array}$ & $\begin{array}{l}13 \\
(21)\end{array}$ & $\begin{array}{l}16(26) \\
/ 4(13)\end{array}$ & $24(8)$ & $\begin{array}{l}52(43) \\
/ 19(29)\end{array}$ & $22(26)$ & $\begin{array}{l}25(18) \\
/ 12(12)\end{array}$ & $10(1)$ & $\begin{array}{l}22 \\
(42)\end{array}$ \\
\hline
\end{tabular}

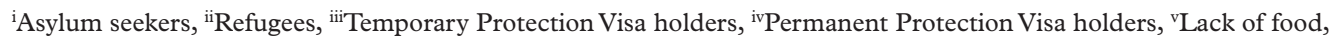

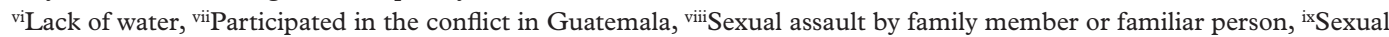
assault by a stranger, ${ }^{\mathrm{x}}$ Sexual molestation, ${ }^{\mathrm{x}} \mathrm{R}$ ape 


\section{Trauma history and mental ill health}

While several studies implicitly report a dose-response relationship between mental ill health and the number of endorsed trauma items, only a few make the suggestion explicitly. ${ }^{47,}{ }^{48}$ Among Somali refugees in Australia, trauma experienced directly by the individual was found to predict PTSD symptomatology and somatisation, while trauma experienced by a person's family members predicted levels of depression and anxiety. ${ }^{65}$

Torture is reported as a particularly strong predictor of mental ill health. ${ }^{57} \mathrm{~A}$ history of torture is found to predict both physical and psychological symptoms. Physical symptoms were found to be twice as frequent and psychological symptoms around two to three times as frequent among torture survivors as among non-tortured newly arrived asylum seekers in Denmark. ${ }^{58}$

\section{Discussion}

The aim of this review was to describe and appraise the existing literature concerning prevalence of torture and other war-related PTEs among forced migrants in high-income countries. It was found that, with few exceptions, prevalence of torture and other war-related PTEs were high in the samples studied, although prevalence rates of torture varied greatly overall from between 1 and $76 \%$ (median 27\%). Torture prevalence was, in general, higher in men and in older age groups. Torture had often occurred in a context of several other war-related PTEs. The violent war-related PTEs most commonly endorsed were "being close to death", "unnatural death of a loved one", "combat situation", "imprisonment”, "forced separation from family", and "witnessing acts of violence". The most common instrument to measure trauma history was the HTQ. Most studies were based on small, non-random samples recruited among specific ethnic groups or nationalities, limiting generalisation. Trauma history, torture in particular, was found to be an important background factor for mental ill health. A meta-analysis of the data would not have been meaningful given the heterogenity of the data.

Torture definitions were reported only in a minority of the included studies, and reported history of torture may thus not be comparable. However, studies comparing self-defined torture against the UN definition, show high rates of sensitivity and specificity; $92 \%$ and $82 \%$ respectively in a sample of Middle Eastern refugees, ${ }^{28}$ and $86 \%$ and $91 \%$ respectively in a sample of Somali and Oromo refugees. ${ }^{67}$ The latter study also found that a false positive endorsement of a torture item was related to other types of severe trauma, and false negatives were related to reporting of fewer instances of torture.

The notably low rates of reported sexual violence among the war-related PTEs may be due to the sensitivity of these questions and the context in which epidemiological studies are performed.

Trauma history and prevalence of torture are highly dependent on the background of the group studied and the situation in the place of origin that caused them to migrate. The nature of the conflict or situation, the timing of refuge, and also socio-demographic characteristics influence the probability of having been subjected to certain types of traumata. This must be kept in mind when comparing figures between and within groups. In groups where no epidemiological studies have been carried out, country reports and eye-witness accounts may be the best sources of information in predicting possible trauma levels in certain groups, and what sub-groups are at greatest risk.

Most studies reporting on prevalence of 
trauma history in forced migrants focus on mental health, and most checklists are developed in clinical rather than community settings. The most commonly use checklist, the HTQ, was for example designed in relation to Southeast Asian refugee clinical samples in the 1980 's, ${ }^{68}$ and its trauma items checklist should be understood in this context. ${ }^{69}$

The instrument used and the trauma items included, as well as their definitions, are important factors in how and what items can be reported. This issue has been dealt with in different ways: by having few broad trauma items ${ }^{31}$ or having a large number of more specific trauma items, ${ }^{70}$ and by including an "everything else"-item in the trauma history checklist. The first solution may lead to high prevalence rates of those few broad trauma items, giving little information of what events have been experienced, and leaving few respondents as comparison group. The second is time-consuming and may be distressing and cause re-traumatisation in the respondents. ${ }^{71}$ The third option allows the study to include PTEs beyond those specifically asked for, with or without specifying what that may be, but compromises the specificity of the checklist. Another approach is to perform semi-structured interviews that are later coded into different categories of trauma. Leaving the initiative and power to the respondents may be a good choice, but repeating a traumatic experience in one's own words may be more distressing than responding to a yes/no question in a trauma history checklist. ${ }^{71}$ Further, problems with recall become more pronounced as recognition memory is more comprehensive than recall memory. ${ }^{72}$ This is particularly relevant in relation to trauma history, as traumatic experiences may affect memory and cognitive function.
Concerning the amount of trauma, or traumatisation, trauma history checklists are rather blunt instruments. Several studies included in this review approximate "amount of trauma" with number of traumata endorsed by each participant. Given the sensitivity of the questions, and the context of epidemiological studies, this may be the only measure available. The average number of traumata was reported and used in models exploring relationships between traumatisation and mental health. While such relationships were found in some studies, such figures should be used with caution. The trauma items themselves are neither comparable, nor carry any information of frequency, severity or subjective response, and in a population like refugees that often have experienced highly traumatic events, the added score on a trauma checklist may better measure the variety in trauma history rather than amount.

The language of forced migration is fraught with politics, and a person labelled asylum seeker in one country may be called illegal entrant or collectively "boat people" in another. "Refugee" may refer to persons in a wide range of situations, from a "refugee proper" who fulfils a specific legal definition, such as that of the 1951 Convention, to someone seeking protection, ${ }^{21}$ to anyone from a refugee-sending country. ${ }^{66,73}$ Among "refugees proper" resettled by the UNHCR in $2014,15.7 \%$ were selected on the basis of being "survivors of violence and/or torture". ${ }^{74}$ The broad range of both particular and more vague uses of the word "refugee" makes it a concept unwise to use without specification.

Post-migration factors and the need for further research

While trauma level (number of different events) is found to be correlated to PTSD, or 
to other types of distress, many studies also find that post-migration stressors like detention, ${ }^{40,62,75}$ temporary, rather than permanent, residence permits, ${ }^{38,40,63,76}$ separation from family ${ }^{40,54}$ worries about family left behind, ${ }^{36,65}$ feelings of not being secure, ${ }^{59}$ and social and economic strain and alienation ${ }^{64}$ may also be related to PTSD, when controlling for trauma levels. In some cases, the effects of post migration-stressors were found to be larger than that of trauma history. ${ }^{35,36,53}$ While post-migration stressors may trigger PTSD symptoms, they are not their primary cause, and it is important that further research is carried out in both these fields.

Migration- and post-migration-related trauma have been given little attention in comparison with pre-migration trauma, but it is increasingly important to take into account. With the changing policies of refugee-receiving countries and stricter border management, migrants are forced to put their lives at stake in order to seek refuge.

It is imperative that further knowledge is gained concerning the prevalence of torture among forced migrants; the signatories of the UN Convention against Torture have agreed to provide opportunities for rehabilitation and redress for torture survivors. A first step towards fulfilling this promise is to identify the groups and individuals concerned.

Finding ways to collect comparable data concerning torture experiences and other sensitive questions, such as sexual violence, in an as unobtrusive way as possible is of great importance. Our research group is currently examining the validity of a general protocol for assessing prevalence of torture and trauma history at the community level.

\section{Strengths and limitations}

We performed a systematic review using standard searching techniques, limiting the results to peer-reviewed research articles in English. Including grey literature and other languages than English would have yielded more data. ${ }^{77-80}$ Studies measuring trauma history as a background variable were included only if they reported prevalence rates in a satisfactory way. Contacting authors for additional data would have resulted in a more comprehensive overview of existing data on torture and trauma history prevalence.

The wide range of type and focus of the studies reporting on trauma history in forced migrants makes standardised appraisal difficult. The specific features of the included data varied. Non-probabilistic samples were generally included in the samples and varying data collection techniques were used. Further, the included studies have used different instruments and varying definitions of torture, meaning that the reported torture prevalence figures are not necessarily comparable. Only descriptive, rather than comparative appraisal, was therefore conducted.

Despite the limitations of the present study, there is a strong case for high trauma history levels, including torture, in all groups of forced migrants. The present study provides a detailed and thought-provoking review of the reported prevalence rates of torture and war-related PTEs in forced migrants as well as related methodological issues in the current research literature.

\section{Acknowledgements}

We thank the Swedish Red Cross care unit and the joint steering board for research at the Swedish Red Cross and the Swedish Red Cross University College. We also thank two anonymous reviewers for useful comments. This research was carried out with support from the Swedish Red Cross care unit and the Swedish Red Cross University College. 
References

1. Silove DM. The psychosocial effects of torture, mass human rights violations, and refugee trauma: toward an integrated conceptual framework. J Nerv Ment Dis. 1999 Apr;187(4):200-7.

2. United Nations General Assembly. Convention against torture and other cruel, inhuman or degrading treatment or punishment $(10$ December 1984).

3. World Medical Association. Declaration of Tokyo. World Medical Assembly; October 1975.

4. United Nations Office of the High Commission for Human Rights. Manual on the Effective Investigation and Documentation of Torture and Other Cruel, Inhuman or Degrading Treatment or Punishment (the "Istanbul Protocol"). New York and Geneva: United Nations; 2004.

5. Amnesty International. Torture in 2014: 30 years of broken promises. Amnesty International; 2014 (ACT 40/004/2014). 2014.

6. United Nations High Commissioner for Refugees. UNHCR Global Trends 2014. Geneva: United Nations High Commissioner for Refugees; 2015.

7. Steel Z, Chey T, Silove DM, Marnane C, Bryant $\mathrm{RA}$, Van Ommeren $\mathrm{MH}$. Association of torture and other potentially traumatic events with mental health outcomes among populations exposed to mass conflict and displacement: a systematic review and meta-analysis. JAMA. 2009 Aug 5;302(5):537-49.

8. Green BL. Traumatic stress and disaster: Mental health effects and factors influencing adaptation. International review of psychiatry. 1996; 2:177210.

9. Gershoff ET, Aber JL, Ware A, Kotler JA. Exposure to 9/11 among youth and their mothers in New York City: enduring associations with mental health and sociopolitical attitudes. Child Dev. 2010 Jul-Aug;81(4):1142-60.

10. Nordanger DO, Hysing M, Posserud MB, Lundervold AJ, Jakobsen R, Olff M, Stormark KM. Posttraumatic responses to the July 22, 2011 Oslo Terror among Norwegian high school students. J Trauma Stress. 2013 Dec;26(6):67985.

11. Arnberg FK, Bergh Johannesson K, Michel P-O. Prevalence and duration of PTSD in survivors 6 years after a natural disaster. J Anxiety Disord. 2013 Apr;27(3):347-52.

12. Kulkarni M, Pole N. Psychiatric distress among Asian and European American survivors of the 1994 Northridge earthquake. J Nerv Ment Dis. 2008 Aug; 196(8):597-604.

13. Galea S, Nandi A, Vlahov D. The Epidemiology of Post-Traumatic Stress Disorder after Disasters. Epidemiol Rev. 2005;27:78-91.

14. Ikin JF, Creamer MC, Sim MR, McKenzie DP. Comorbidity of PTSD and depression in Korean War veterans: Prevalence, predictors, and impairment. J Affect Disord. 2010 Sep;125(1-3):27986.

15. Jamil H, Nassar-McMillan S, Lambert R. The aftermath of the Persian Gulf War: mental health issues among Iraqi-American veterans. Ethn Dis. 2005 Winter;15(1 Suppl 1):S1-105.

16. Kalt A, Hossain M, Kiss L, Zimmerman C. Asylum seekers, violence and health: a systematic review of research in high-income host countries. Am J Public Health. 2013 Mar;103(3):e30-42.

17. Roberts B, Browne J. A systematic review of factors influencing the psychological health of conflict-affected populations in low- and middle-income countries. Glob Public Health. 2011;6(8):814-29.

18. Fazel M, Wheeler J, Danesh J. Prevalence of serious mental disorder in 7000 refugees resettled in western countries: a systematic review. Lancet. 2005 Apr 9-15;365(9467):1309-14.

19. Wilczynski NL, Haynes RB, Team H. Optimal search strategies for identifying mental health content in MEDLINE: an analytic survey. Ann Gen Psychiatry. 2006 Mar 23;5:4.

20. Association AP. Diagnostic and statistical manual of mental disorders (5th ed.). Arlington, VA: Association AP; 2013.

21. Elklit A, Ostergard Kjaer K, Lasgaard M, Palic S. Social support, coping and posttraumatic stress symptoms in young refugees. Torture. 2012; 22: 11-23.

22. Ellis BH, MacDonald HZ, Lincoln AK, Cabral HJ. Mental health of Somali adolescent refugees: the role of trauma, stress, and perceived discrimination. J Consult Clin Psychol. 2008 Apr;76(2):184-93.

23. Mghir R, Raskin A. The psychological effects of the war in Afghanistan on young Afghan refugees from different ethnic backgrounds. Int J Soc Psychiatry. 1999;45:29-36.

24. Willard CL, Rabin M, Lawless M. The prevalence of torture and associated symptoms in United States Iraqi refugees. J Immigr Minor Health. 2014 Dec;16(6):1069-76.

25. Boyle MH. Guidelines for evaluating prevalence studies. Evidence Based Mental Health. 1998; $1: 37-9$.

26. Cooper C, Selwood A, Livingston G. The prevalence of elder abuse and neglect: a systematic review. Age Ageing. 2008 Mar;37(2):151-60.

27. Momartin S, Silove D, Manicavasagar V, Steel Z. 
Range and dimensions of trauma experienced by Bosnian refugees resettled in Australia. Australian Psychologist. 2002;37:149-55.

28. Montgomery E and Foldspang A. Criterion-related validity of screening for exposure to torture. Dan Med Bull. 1994 Nov;41(5):588-91.

29. Norris AE, Aroian KJ. Assessing reliability and validity of the Arabic language version of the Posttraumatic Diagnostic Scale (PDS) symptom items. Psychiatry Res. 2008 Sep 30;160(3):327-34.

30. Hondius AJK, Van Willigen LHM, Kleijn WC, Van der Ploeg HM. Health problems among Latin-American and middle-eastern refugees in the Netherlands: relations with violence exposure and ongoing sociopsychological strain. J Trauma Stress. 2000 Oct;13(4):619-34.

31. Shannon PJ, Cook T, Vinson GA, Wieling E, Letts J. Torture, War Trauma and Mental Health Symptoms of Newly Arrived Karen Refugees. J Loss Trauma. 2014;20:577-90.

32. Alpak G, Unal A, Bulbul F, Sagaltici E, BezY, Altindag A, Dalkilic A, Savas HA. Post-traumatic stress disorder among Syrian refugees in Turkey: A cross-sectional study. Int J Psychiatry Clin Pract. 2015 Mar;19(1):45-50

33. Cleveland J and Rousseau C. Psychiatric symptoms associated with brief detention of adult asylum seekers in Canada. Can J Psychiatry. 2013 Jul;58(7):409-16.

34. Poole GE, Galpin G. Prevalence of victims of torture in the health screening of quota refugees in New Zealand during 2007-2008 and implications for follow-up care. N Z Med J. 2011 Jul $8 ; 124(1338): 18-24$

35. Schweitzer RD, Brough M, Vromans L, AsicKobe M. Mental health of newly arrived Burmese refugees in Australia: contributions of premigration and post-migration experience. Aust $\mathrm{N}$ Z J Psychiatry. 2011 Apr;45(4):299-307.

36. Nickerson A, Bryant RA, Steel Z, Silove D, Brooks R. The impact of fear for family on mental health in a resettled Iraqi refugee community. J Psychiatr Res. 2010 Mar;44(4):229-35.

37. Schwarz-Nielsen KH, Elklit A. An evaluation of the mental status of rejected asylum seekers in two Danish asylum centers. Torture. 2009;19:519.

38. Silove DM, Steel Z, McGorry PD, Mohan P. Trauma exposure, postmigration stressors, and symptoms of anxiety, depression and post-traumatic stress in Tamil asylum-seekers: comparison with refugees and immigrants. Acta Psychiatr Scand. 1998 Mar;97(3):175-81.

39. Heeren M, Mueller J, Ehlert U, Schnyder U, Copiery N, Maier T. Mental health of asylum seekers: a cross-sectional study of psychiatric disorders. BMC Psychiatry. 2012 Aug 17;12:114.

40. Steel Z, Silove DM, Brooks RT, Momartin S, Alzuhairi B, Susljik I. Impact of immigration detention and temporary protection on the mental health of refugees. Br J Psychiatry. 2006 Jan;188:58-64.

41. Lie B. A 3-year follow-up study of psychosocial functioning and general symptoms in settled refugees. Acta Psychiatr Scand. 2002 Dec;106(6):415-25.

42. Roth G, Ekblad S, Ågren H. A longitudinal study of PTSD in a sample of adult mass-evacuated Kosovars, some of whom returned to their home country. Eur Psychiatry. 2006 Apr;21(3):152-9.

43. Loutan L, Bollini P, Pampallona S, De Haan DB, Gariazzo F. Impact of trauma and torture on asylum-seekers. Eur J Pub Health. 1999;9: 93-6.

44. Blair RG. Risk factors associated with PTSD and major depression among Cambodian refugees in Utah. Health Soc Work. 2000 Feb;25(1):23-30.

45. Rasmussen A, Crager M, Baser RE, Chu T, Gany F. Onset of posttraumatic stress disorder and major depression among refugees and voluntary migrants to the United States. J Trauma Stress. 2012 Dec;25(6):705-12.

46. Taloyan M, Johansson SE, Sundquist J, Kocturk TO, Johansson LM. Psychological distress among Kurdish immigrants in Sweden. Scand J Public Health. 2008 Mar;36(2):190-6.

47. Sabin ME, Lopes Cardozo B, Nackerud L, Kaiser R, Varese L. Factors associated with poor mental health among Guatemalan refugees living in Mexico 20 years after civil conflict. JAMA. 2003 Aug 6;290(5):635-42.

48. Marshall GN, Schell TL, Elliott MN, Berthold S, Chun C-A. Mental health of Cambodian refugees 2 decades after resettlement in the United States. JAMA. 2005 Aug 3;294(5):571-9.

49. Matheson K, Jorden S, Anisman H. Relations between trauma experiences and psychological, physical and neuroendocrine functioning among Somali refugees: mediating role of coping with acculturation stressors. J Immigr Minor Health. 2008 Aug; 10(4):291-304.

50. Craig CD, Sossou M-A, Schnak M, Essex H. Complicated grief and its relationship to mental health and well-being among Bosnian refugees after resettlement in the United States: implications for practice, policy, and research. Traumatology. 2008;14:103-15.

51. Robjant K, Robbins I, Senior V. Psychological distress amongst immigration detainees: a crosssectional questionnaire study. Br J Clin Psychol. 2009 Sep;48(Pt 3):275-86. 
52. Ai AL, Peterson C, Ubelhor D. War-related trauma and symptoms of posttraumatic stress disorder among adult Kosovar refugees. J Trauma Stress. 2002 Apr;15(2):157-60.

53. Cheung P. Posttraumatic stress disorder among Cambodian refugees in New Zealand. Int J Soc Psychiatry. 1994 Spring;40(1):17-26.

54. Turner SW, Bowie C, Dunn G, Shapo L and Yule W. Mental health of Kosovan Albanian refugees in the UK. Br J Psychiatry. 2003 May;182:444-8.

55. Rousseau C, Mekki-Berrada A, Moreau S. Trauma and extended separation from family among Latin American and African refugees in Montreal. Psychiatry. 2001 Spring;64(1):40-59.

56. Hauff E, Vaglum P. Vietnamese boat refugees: the influence of war and flight traumatization on mental health on arrival in the country of resettlement. A community cohort study of Vietnamese refugees in Norway. Acta Psychiatr Scand. 1993 Sep;88(3):162-8.

57. Jaranson JM, Butcher J, Halcon L, Johnson DR, Robertson C, Savik K, Spring M, Westermeyer J. Somali and Oromo refugees: Correlates of torture and trauma history. Am J Public Health. 2004 Apr;94(4):591-8.

58. Masmas TN, Moller E, Buhmannr C, Bunch V, Jensen JH, Hansen TN, Jørgensen LM, Kjaer C, Mannstaedt M, Oxholm A, Skau J, Theilade L, Worm L, Ekstrøm M. Asylum seekers in Denmark-a study of health status and grade of traumatization of newly arrived asylum seekers. Torture. 2008; 18:77-86.

59. Sundquist J, Johansson SE. The influence of exile and repatriation on mental and physical health. A population-based study. Soc Psychiatry Psychiatr Epidemiol. 1996;31:21-8.

60. Blair RG. Mental health needs among Cambodian refugees in Utah. International Social Work. 2001;44:179-96.

61. Eytan A, Bischoff A, Rrustemi I, Durieux S, Lou$\tan$ L, Gilbert M, Bovier PA. Screening of mental disorders in asylum-seekers from Kosovo. Aust N Z J Psychiatry. 2002 Aug;36(4):499-503.

62. Ichikawa $M$, Nakahara $S$, Wakai S. Effect of postmigration detention on mental health among Afghan asylum seekers in Japan. Aust N Z J Psychiatry. 2006 Apr;40(4):341-6.

63. Johnston V, Allotey P, Mulholland K, Markovic M. Measuring the health impact of human rights violations related to Australian asylum policies and practices: a mixed methods study. BMC Int Health Hum Rights. 2009 Feb 3;9:1.

64. Lindencrona F, Ekblad S, Hauff E. Mental health of recently resettled refugees from the Middle East in Sweden: the impact of pre-resettlement trauma, resettlement stress and capacity to handle stress. Soc Psychiatry Psychiatr Epidemiol. 2008 Feb;43(2):121-31.

65. Schweitzer R, Melville F, Steel Z, Lacherez P. Trauma, post-migration living difficulties, and social support as predictors of psychological adjustment in resettled Sudanese refugees. Aust N Z J Psychiatry. 2006 Feb;40(2):179-87.

66. Steel Z, Silove D, Phan T, Bauman A. Long-term effect of psychological trauma on the mental health of Vietnamese refugees resettled in Australia: a population-based study. Lancet. 2002 Oct 5;360(9339):1056-62.

67. Westermeyer J, Hollifield M, Spring M, Johnson D, Jaranson J. Comparison of two methods of inquiry for torture with East African refugees: single query versus checklist. Torture. 2011;21:15572.

68. Mollica RF, Caspi-Yavin Y, Bollini P, Truong T, Tor S, Lavelle J. The Harvard Trauma Questionnaire. Validating a cross-cultural instrument for measuring torture, trauma, and posttraumatic stress disorder in Indochinese refugees. J Nerv Ment Dis. 1992 Feb;180(2):111-6.

69. Hollifield M, Warner TD, Lian N, Krakow B, Jenkins JH, Kesler J, Stevenson J, Westermeyer J. Measuring trauma and health status in refugees A critical review. JAMA. 2002 Aug 7;288(5):61121.

70. Hollifield M, Warner TD, Jenkins JH, SinclairLian N, Krakow B, Eckert V, Karadaghi P, Westermeyer J. Assessing war trauma in refugees: properties of the Comprehensive Trauma Inventory-104. J Trauma Stress. 2006 Aug;19(4):52740 .

71. Silove D, McIntosh P, Becker R. Risk of retraumatisation of asylum-seekers in Australia. Aust N Z J Psychiatry. 1993 Dec;27(4):606-12.

72. Willis GB, Gonzalez A. Methodological issues in the use of survey questionnaires to assess the health effects of torture. J Nerv Ment Dis. 1998 May;186(5):283-9.

73. Kroll J, Yusuf AI and Fujiwara K. Psychoses, PTSD, and depression in Somali refugees in Minnesota. Soc Psychiatry Psychiatr Epidemiol. 2011 Jun;46(6):481-93.

74. United Nations High Commission Refugees. UNHCR Global Resettlement Statistical Report 2014. Geneva; United Nations; 2015.

75. Steel Z, Momartin S, Bateman C, Hafshejani A, Silove DM, Everson N, Roy K, Dudley M, Newman L, Blick B, Mares S. Psychiatric status of asylum seeker families held for a protracted period in a remote detention centre in Australia. Aust N Z J Public Health 2004 Dec;28(6):527-36. 
76. Momartin S, Steel Z, Coello MJ, Aroche J, Silove DM, Brooks RT. A comparison of the mental health of refugees with temporary versus permanent protection visas. Med J Aust 2006;185:35761

77. Loutan L, Bierens de Haan D, Subilia L. [The health of asylum seekers: from communicable disease screening to post-traumatic disorders]. Bull Soc Pathol Exot. 1997;90(4):233-7.

78. Carrer S, Meuti V, Catino E, Pucci D, Lafuente M, Colosimo F, Aragona M, Mazzetti M, Maisano B, Geraci S. [Immigration, trauma, living difficulties and psychopathology: a preliminary study in a primary care setting]. Riv Psichiatr. 2011 Mar-Apr;46(2):129-39.

79. Gernaat HB, Malwand AD, Laban CJ, Komproe I, de Jong JT. [Many psychiatric disorders in Afghan refugees with residential status in Drenthe, especially depressive disorder and post-traumatic stress disorder]. Ned Tijdschr Geneeskd. 2002 Jun 15;146(24):1127-31.

80. Nygård M, Malterud K. Enkel kartlegging av posttraumatisk stressforstyrrelse hos bosniske krigsflyktninger i Norge [Rapid screening for post-traumatic stress disorder among Bosnian war refugees.] Tidsskr Nor Laegeforen. 1995 Jun 20;115(16):1971-4. 


\section{Appendix A}

Table: Article matrix of the included studies, including quality appraisal

CTEI: Communal Traumatic Events Inventory; HTQ: Harvard Trauma Questionnaire; LESHIS: Live Events and Social History Schedule; NLAAS: National Latino and Asian American Study; PDS:

Posttraumatic Stress Diagnostic Scale; SLESQ: Stressful Life Events Screening Questionnaire; TLEQ:

Trauma Life Events Questionnaire; WTQ: War Trauma Questionnaire;WTS: War Trauma Scale; TPV:

Temporary protection visa; PPV: Permanent protection visa.

\begin{tabular}{ll}
\hline Author & Study design \\
Country & Sampling meth- \\
Ethnicityl & od Recruitment \\
nationality & context \\
Legal status & Sample size n \\
Date & $\begin{array}{l}\text { Response rate } \\
\end{array}$ \\
& $(\%)$
\end{tabular}

$\begin{array}{lll}\begin{array}{l}\text { Type of } \\ \text { measure/ }\end{array} & \begin{array}{l}\text { Included } \\ \text { participants } \mathbf{n}^{\mathrm{a}}\end{array} & \text { Torture } \mathbf{n}(\%)^{\mathbf{b}} \\ \begin{array}{l}\text { Instrument-no. } \\ \text { of items }\end{array} & (\mathrm{M}) & \\ & \end{array}$

Witnessed torture $\mathbf{n}(\%)^{b}$

Ai et al. (52)

Cross-sectional

Self report/

$129(58 / 71)$

$54(42)$

USA

Kosovar

Convenience

CTEI-24

Refugees

1999-2000

Refugee

resettlement

agencies,

community

(90)

Alpak et al.(32)

Turkey

Syrian

Refugees

Random

Refugee camp

Structured

interview/

SLESQ-14

\begin{tabular}{lllll}
$\begin{array}{l}\text { Blair }(60) \\
\text { USA }\end{array}$ & $\begin{array}{l}\text { Cross-sectional } \\
\text { Random } \\
\text { Cambodian }\end{array}$ & $\begin{array}{l}\text { Structured } \\
\text { interview/ }\end{array}$ & 124 (75/49) & $26(21)$ \\
$\begin{array}{l}\text { Refugees } \\
1991\end{array}$ & $150(82)$ & WTS-42 & & \\
& & & & \\
Cheung (53) & Cross-sectional & Structured & $223(119 / 104)$ & $51(23)$ \\
$\begin{array}{l}\text { New Zealand } \\
\text { Cambodian }\end{array}$ & $\begin{array}{l}\text { Total } \\
\text { Community }\end{array}$ & $\begin{array}{l}\text { interview } \\
\text { LESHIS-20 }\end{array}$ & & \\
\hline
\end{tabular}


${ }^{a}$ Included participants include those who are relevant for the present study, thus not including reference groups or comparison groups.

"Where torture items are indicated as something other than "torture", the item is included in the column.

${ }^{\mathrm{c}}$ The quality appraisal checklist can be found in Appendix B.

Secondary torture $\mathbf{n}(\%)^{\mathbf{b}}$
Three most common traumas. Item, $\mathbf{n}(\%)$

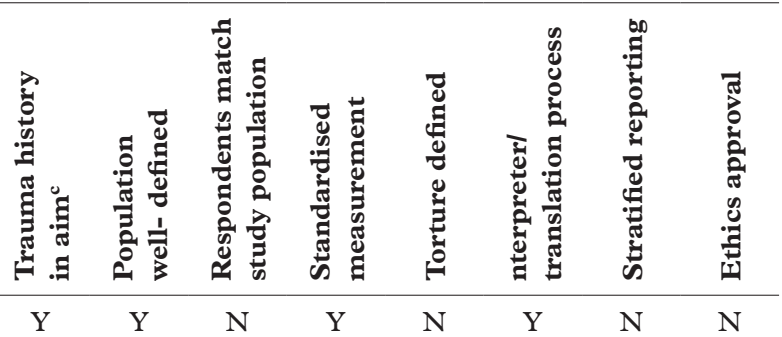

Evacuated from town 120 (93)

Stolen possessions 108 (84), Separated from loved ones 104

(81)

Had been in a region that is $\begin{array}{lllllllll}\mathrm{N} & \mathrm{Y} & \mathrm{Y} & \mathrm{Y} & \mathrm{N} & \mathrm{Y} & \mathrm{NA} & \mathrm{Y}\end{array}$ affected by war 324 (92) Experienced/witnessed the death of a close friend or a family member (except spouse/child) 233 (66) Saw and touched dead bodies apart from funerals 178 (51)

Lost relatives during this time because of the war 105 (85) Lost one or more immediate family members during Pol Pot time 97 (78) Saw dead bodies during Pol Pot time 91 (73)

Forced labour 180 (81) Loss of property/livelihood 145 (65)

Torture 51 (23)

$\begin{array}{llllllll}\mathrm{Y} & \mathrm{Y} & \mathrm{Y} & \mathrm{Y} & \mathrm{N} & \mathrm{Y} & \mathrm{N} & \mathrm{N} \\ & & & & & & \\ & & & & & & & \\ & & & & & & & \\ & & \mathrm{YA} & \mathrm{Y} & \mathrm{N} & \mathrm{Y} & \mathrm{N} & \mathrm{N}\end{array}$




Author
Country
Ethnicity/
nationality
Legal status
Date

Cleveland and

Rousseau (33)

Canada

Detained/

non-detained

asylum seekers

2010-2011

Craig et al. (50)

USA

Bosnian

Refugees

2005

Elklit et al. (21)

Denmark

Bosnian

Asylum seekers/

refugees

Eytan et al. (61)

Switzerland

Kosovar

Asylum seekers

1998

Hauff and Vaglum

(56)

Norway

Vietnamese

Refugees

Heeren et al. (39)

Switzerland

Asylum seekers

resident $0-5$

months/12-26

months

2008-2009

\section{Study design \\ Sampling meth- \\ od Recruitment \\ context \\ Sample size $\mathbf{n}$ \\ Response rate \\ (\%)}

Type of

measurel

Included

Instrument-no.

of items

participants $\mathbf{n}^{\mathrm{a}}$

\section{Torture n (\%) ${ }^{\mathbf{b}} \quad$ Witnessed}

torture $\mathbf{n}(\%)^{\mathrm{b}}$

$\begin{array}{llll}\text { Cross-sectional } & \text { Structured } & 122(40 / 82) & 52(43) / \\ \text { Consecutive/ } & \text { interview } & 166(33 / 33) & 19(29) \\ \begin{array}{l}\text { Convenience } \\ \text { Detention }\end{array} & \text { HTQ-20 } & & \end{array}$

centre,/

Community

$135(90) / 66$

(100)

Cross-sectiona

Self report

126

Random

TLEQ-23

Community

(25)

Cross-sectional

Self report

$119(39 / 80)$

27 (23)

Total

HTQ-23

Boarding school

165 (72)

Cross-sectional

Structured

$319(89 / 230)$

Consecutive

interview

Medical

screening

Cross-sectional

Semi-structured

$145(31 / 114)$

Consecutive

interview

Community

148 (98)

Cross-sectional

Random

Structured

$43(12 / 31)$

interview

$/ 43(14 / 29)$

$11(26) / 11(26)$

HTQ-23

Community

126 (68) 


\section{Secondary Three most common}

$\begin{array}{ll}\begin{array}{l}\text { Secondary } \\ \text { torture } \mathbf{n}(\%)^{\mathrm{b}}\end{array} & \begin{array}{l}\text { Three most common } \\ \text { traumas. Item, } \mathbf{n}(\%)\end{array}\end{array}$

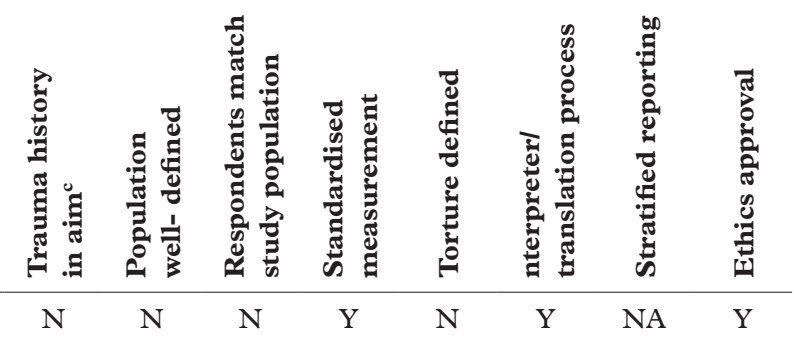

Being close to death $110(90) / 61$

(92) Beaten or assaulted $82(67) /$

50 (76) Family member's health or safety seriously threatened 81

(66)/ 47 (71)

$\begin{array}{llllllllll}\text { Unexpected death of a loved one } & \text { N } & \text { Y } & \text { N } & \text { Y } & \text { NA } & \text { Y } & \text { NA } & \text { N }\end{array}$ 101 (80) Experienced events related to living in a war zone 93

(74) Loved one survived life-threatening event 66 (52).

Loss of possessions 59 (50)

Firing/shelling 53 (45) Death

$\begin{array}{llllllll}\text { N } & \text { Y } & \text { NA } & \text { Y } & \text { N } & \text { Y } & \text { NA } & \text { U }\end{array}$

threats 53 (45)

Situation of war 156 (49)

Personal violence 69 (22)

$\begin{array}{llllllll}\mathrm{N} & \mathrm{Y} & \mathrm{NA} & \mathrm{N} & \mathrm{NA} & \mathrm{N} & \mathrm{NA} & \mathrm{N}\end{array}$

Imprisonment 47 (15)

Experience of bombing, fires, shooting 62 (90) Witnessed war

$\begin{array}{llllllll}\mathrm{N} & \mathrm{Y} & \mathrm{NA} & \mathrm{N} & \mathrm{NA} & \mathrm{Y} & \mathrm{NA} & \mathrm{N}\end{array}$

injuries or deaths 48 (69) War

exposure: life danger or wounded

$36(52)$

Forced separation from family member 18 (42)/ 19 (44), Unnatural death of family member or friend, 17 (40)/ 18

(42), Being close to death, 14

(33)/ 20 (47)

$\begin{array}{lllllllll}\mathrm{N} & \mathrm{N} & \mathrm{N} & \mathrm{Y} & \mathrm{N} & \mathrm{Y} & \mathrm{NA} & \mathrm{Y}\end{array}$ 


\begin{tabular}{ll}
\hline Author & Study design \\
Country & $\begin{array}{l}\text { Sampling meth- } \\
\text { od Recruitment }\end{array}$ \\
Ethnicityl & context \\
nationality & Sample size $\mathbf{n}$ \\
Legal status & $\begin{array}{l}\text { Response rate } \\
\text { Date }\end{array}$ \\
& $(\%)$
\end{tabular}

Hondius et al. (30)

The Netherlands

Middle Eastern,

Latin American/

Turkish,Iranian

Refugees and

Asylum seekers

1982-1987/1988

Ichikawa et al. (62)

Japan

Afghan

Asylum seekers

2002-2003

Jaranson et al. (57)

USA

Somali/Oromo

Refugees

1999-2001

Johnston et al. (63)

Australia

Refugees TPV/

PPV holders

2004-2005

Lie (41)

Norway

Bosnian

Refugees

1994-1995

Lindencrona et al.

(64)

Sweden

Iraqi

Refugees

2002-2004

Loutan et al. (43)

Switzerland

Asylum seekers

1993-1994

(\%)
Cross-sectional

Consecutive, convenience

Refugee health centre/refugee reception centre, community

Cross-sectional Convenience Lawyers and NGOs 73 (75)

Cross-sectional

Convenience

Community 1167 (97)

Cross-sectional Convenience

Community

Longitudinal

Consecutive

Community

554 (58)

Cross-sectional

Consecutive

Resettlement support programme

Cross-sectional

Consecutive

Entry medical

assessment

$575(100)$

\begin{tabular}{|c|c|}
\hline $\begin{array}{l}\text { Type of } \\
\text { measurel } \\
\text { Instrument-no. }\end{array}$ & $\begin{array}{l}\text { Included } \\
\text { participants } \mathbf{n}^{\mathrm{a}} \\
(\mathrm{F} / \mathrm{M})\end{array}$ \\
\hline
\end{tabular}

Torture n (\%)

Witnessed

torture $\mathbf{n}(\%)^{b}$
Medical records/

Semi structured

$480(147 / 333) /$

$210(44) /$

$/ 156(53 / 103)$

$118(76)$

interview

$56(12) / 52(33)$

Structured

$55(2 / 53)$

$37(67)$

interview

HTQ-17

Structured

$1134(529 / 605)$

405 (36)

interview Single

query, checklist of

torture items

Structured

$71(31 / 40) 60$

interview

(33/27)

Structured

$343(176 / 167)$

$48(14)$

$137(40)$

interview

HTQ-15

Structured

$112(43 / 69)$

interview /3

44 (40) torture/

systematic assault

\section{Self report $/ 8$}

$573(208 / 365)$

$104(18)$ 
Secondary

torture $\mathbf{n}(\%)^{\mathbf{b}}$
Three most common

traumas. Item, n (\%)
Persecution of family/friends 320 (67)/ 138 (88) Arrest, imprisonment, camp 230 (48)/ 130 (83) Very difficult flight 78 (16)/ 14 (9)

Being close to death 45 (82) Combat situation 44 (80) Forced separation from family members $44(80)$
$\begin{array}{lllllllll}\mathrm{N} & \mathrm{Y} & \mathrm{NA} & \mathrm{Y} & \mathrm{N} & \mathrm{Y} & \mathrm{NA} & \mathrm{Y}\end{array}$

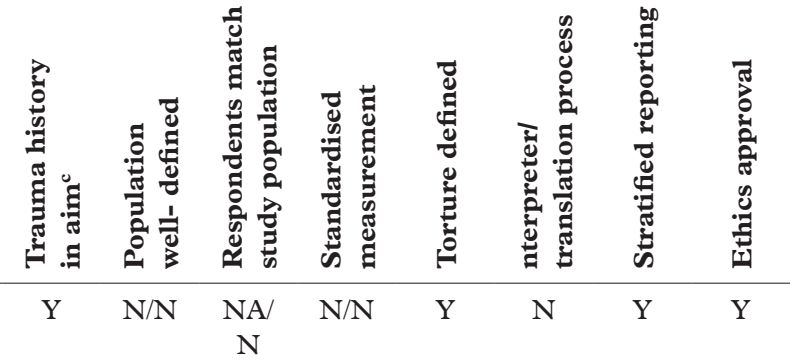

$\begin{array}{llllllllllllllll}\text { Personal and/or family experience } & \text { N } & \text { Y } & \text { N } & \text { N } & \text { NA } & \text { Y } & \text { NA } & \text { Y }\end{array}$ of persecution $37(52) / 23(38)$

Been in danger of life 302 (88) $\begin{array}{lllllllll}\mathrm{Y} & \mathrm{Y} & \mathrm{N} & \mathrm{Y} & \mathrm{N} & \mathrm{Y} & \mathrm{Y} & \mathrm{Y}\end{array}$ Experienced war 295 (86) Been living in hiding 233 (68)

Living in a war zone 93 (83) Detention and imprisonment 28 $\begin{array}{lllllllll}\mathrm{N} & \mathrm{N} & \mathrm{NA} & \mathrm{Y} & \mathrm{N} & \mathrm{Y} & \mathrm{NA} & \mathrm{Y}\end{array}$ (28)

Imprisonment 186 (33) Murde of family members 178 (31) $\begin{array}{lllllllll}\text { Y } & \mathrm{N} & \mathrm{NA} & \mathrm{Y} & \mathrm{N} & \mathrm{N} & \mathrm{Y} & \mathrm{N}\end{array}$ Severe beating 173 (30) 


\begin{tabular}{ll}
\hline Author & Study design \\
Country & $\begin{array}{l}\text { Sampling meth- } \\
\text { od Recruitment }\end{array}$ \\
Ethnicityl & context \\
nationality & Sample size $\mathbf{n}$ \\
Legal status & $\begin{array}{l}\text { Response rate } \\
\text { Date }\end{array}$ \\
& $(\%)$
\end{tabular}

Marshall et al. (48)

USA

Cambodian

Refugees

Masmas et al. (58)

Denmark

Asylum seekers

2007

Matheson et al.

(49)

Canada

Somali

Refugees

2003

Momartin et al.

(27)

Australia

Bosnian

Refugees

Montgomery and

Foldspang (28)

Denmark

Middle Eastern

Refugees

1992-1993

Nickerson et al.

(36)

Australia

Mandaean

Refugees

2006-2007

Norris and Aroian

(29)

USA

Arab

Cross-sectional

Convenience

Community

146 (70)

Cross-sectional

Consecutive

Refugee reception

centre

74 (100)

Cross-sectional

Convenience

Community

367 (86)

Immigrants/

Refugees
Type of Included

measurel participants $\mathbf{n}^{\mathbf{a}}$

Instrument-no. (F/M)

of items

\author{
$\begin{array}{ll}\text { Torture n }(\%)^{\text {b }} & \begin{array}{l}\text { Witnessed } \\ \text { torture } \mathbf{n}(\%)^{b}\end{array}\end{array}$ \\ $\begin{array}{ll}\text { Torture n (\%) } & \begin{array}{l}\text { Witnessed } \\ \text { torture n }(\%)^{\mathbf{b}}\end{array}\end{array}$
}

of items 
Secondary

torture $\mathbf{n}(\%)^{\mathbf{b}}$
Three most common

traumas. Item, $\mathbf{n}(\%)$

Near-death due to starvation 483

(99) Experienced a combat situation 480 (98) Forced labor

(like animal or slave) 466 (96)

Persecution 97 (68) Armed conflict 83 (59), Imprisonment $\begin{array}{llllllll}\text { Y } & \text { N } & \text { NA } & \text { Y } & \text { Y } & \text { Y } & \text { Y } & \text { Y }\end{array}$ $62(44)$

Ethnic discrimination 30 (33) $\begin{array}{lllllllll}\mathrm{Y} & \mathrm{Y} & \mathrm{N} & \mathrm{Y} & \mathrm{NA} & \mathrm{N} & \mathrm{Y} & \mathrm{N}\end{array}$ Death of a loved one 30 (33)

Warfare/combat 18 (20)

Evicted from city 92 (73)

$\begin{array}{lllllllll}\mathrm{Y} & \mathrm{Y} & \mathrm{N} & \mathrm{N} & \mathrm{N} & \mathrm{Y} & \mathrm{N} & \mathrm{U}\end{array}$ Separated from family by force 83 (66) Burned down house 77 (61)

$\begin{array}{lllllllll}\mathrm{N} & \mathrm{N} & \mathrm{NA} & \mathrm{N} & \mathrm{Y} & \mathrm{Y} & \mathrm{NA} & \mathrm{N}\end{array}$

Imprisonment 59 (19) Serious injury 31 (10) Combat situation 53 (17)

Military combat or war zone 401 (89) Serious accident, fire, or explosion 318 (70) Imprisonment 218 (48)

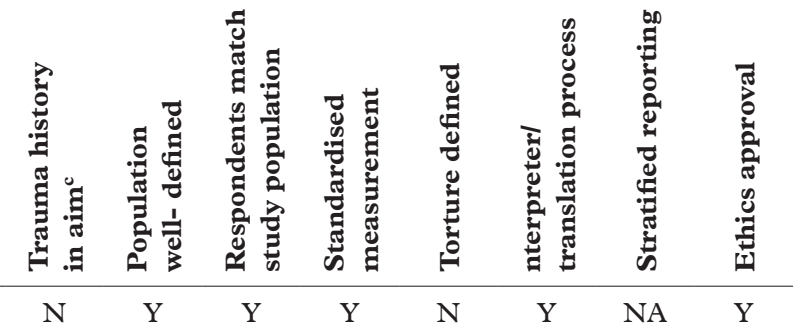

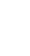




\begin{tabular}{|c|c|c|c|c|c|}
\hline $\begin{array}{l}\text { Author } \\
\text { Country } \\
\text { Ethnicity/ } \\
\text { nationality } \\
\text { Legal status } \\
\text { Date }\end{array}$ & $\begin{array}{l}\text { Study design } \\
\text { Sampling meth- } \\
\text { od Recruitment } \\
\text { context } \\
\text { Sample size n } \\
\text { Response rate } \\
(\%)\end{array}$ & $\begin{array}{l}\text { Type of } \\
\text { measurel } \\
\text { Instrument-no. } \\
\text { of items }\end{array}$ & $\begin{array}{l}\text { Included } \\
\text { participants } \mathbf{n}^{\mathrm{a}} \\
(\mathrm{F} / \mathrm{M})\end{array}$ & Torture n (\%) & $\begin{array}{l}\text { Witnessed } \\
\text { torture } \mathbf{n}(\%)^{\mathrm{b}}\end{array}$ \\
\hline
\end{tabular}

\begin{tabular}{|c|c|c|c|c|c|}
\hline $\begin{array}{l}\text { Poole and Galpin } \\
\text { (34) } \\
\text { New Zealand } \\
\text { Quota refugees } \\
2007-2008\end{array}$ & $\begin{array}{l}\text { Cross-sectional } \\
\text { Consecutive } \\
\text { Refugee entry } \\
\text { medical exam }\end{array}$ & $\begin{array}{l}\text { Interviews, } \\
\text { records }\end{array}$ & $750(391 / 359)$ & $144(19)$ & \\
\hline $\begin{array}{l}\text { Rasmussen et al. } \\
\text { (45) } \\
\text { USA } \\
\text { Refugees }\end{array}$ & $\begin{array}{l}\text { Cross-sectional } \\
\text { Random } \\
\text { Community }\end{array}$ & $\begin{array}{l}\text { Structured } \\
\text { interview } \\
\text { NLAAS-protocol }\end{array}$ & $660(315 / 345)$ & & \\
\hline $\begin{array}{l}\text { Robjant et al. (51) } \\
\text { UK } \\
\text { Asylum seekers }\end{array}$ & $\begin{array}{l}\text { Cross-sectional } \\
\text { Convenience } \\
\text { Detention centre, } \\
\text { community }\end{array}$ & Self report PDS & $146(48 / 98)$ & $41(28)$ & \\
\hline $\begin{array}{l}\text { Roth et al. (42) } \\
\text { Sweden } \\
\text { Kosovar } \\
\text { Mass-evacuated } \\
\text { asylum seekers } \\
1999\end{array}$ & $\begin{array}{l}\text { Longitudinal } \\
\text { Consecutive } \\
\text { Airliner passenger } \\
\text { lists } \\
343(64)\end{array}$ & $\begin{array}{l}\text { Structured } \\
\text { interview } \\
\text { HTQ-17 }\end{array}$ & $218(122 / 96)$ & $90(53)$ & \\
\hline $\begin{array}{l}\text { Rousseau et al. } \\
\text { (55) } \\
\text { Canada } \\
\text { Latin American/ } \\
\text { African } \\
\text { Asylum seekers }\end{array}$ & $\begin{array}{l}\text { Cross-sectional } \\
\text { Convenience } \\
\text { Community } \\
\text { organizations } \\
153(77)\end{array}$ & $\begin{array}{l}\text { Semi-structured } \\
\text { interview }\end{array}$ & $60 / 53$ & $5(8) / 21(40)$ & \\
\hline $\begin{array}{l}\text { Sabin et al. (47) } \\
\text { Mexico } \\
\text { Guatemalan } \\
\text { Refugees } \\
2000\end{array}$ & $\begin{array}{l}\text { Cross-sectional } \\
\text { Random } \\
\text { Refugee camps } \\
183 \text { (93) }\end{array}$ & $\begin{array}{l}\text { Structured } \\
\text { interview } \\
\text { HTQ-19 }\end{array}$ & $170(99 / 71)$ & $24(14)$ & $54(32)$ \\
\hline $\begin{array}{l}\text { Schwarz-Nielsen } \\
\text { and Elklit ( } 37) \\
\text { Denmark } \\
\text { Rejected asylum } \\
\text { seekers } \\
2007\end{array}$ & $\begin{array}{l}\text { Cross-sectional } \\
\text { Convenience } \\
\text { Asylum centres } \\
146(36)\end{array}$ & $\begin{array}{l}\text { Self report } \\
\text { HTQ-17 }\end{array}$ & $53(19 / 34)$ & $22(42)$ & \\
\hline
\end{tabular}


Secondary

torture $\mathbf{n}(\%)^{b}$
Three most common

traumas. Item, $\mathbf{n}(\%)$

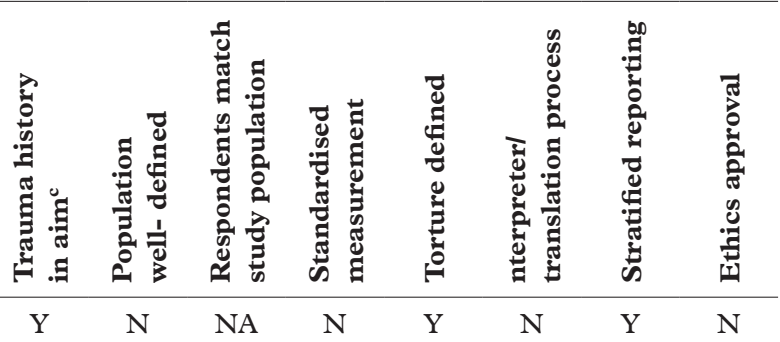

$\begin{array}{llllllll}\mathrm{Y} & \mathrm{N} & \mathrm{N} & \mathrm{Y} & \mathrm{NA} & \mathrm{Y} & \mathrm{Y} & \mathrm{N}\end{array}$

Unarmed civilian in a war zone 209 (32) Seen bad injury or dead body 202 (35) Civilian exposed to on-going terror 190 (28)

Imprisonment 29 (43)/ 11 (46)/ 11 (24) Military combat or a war zone 29 (43)/ 2 (8)/16 (35)

Non-sexual assault by a stranger $25(37) / 4(17) / 8(17)$

Combat situation 180 (91) Any other situation that was frightening or you felt your life was in danger 149 (87) Being close to death 112 (61)

$12(20) / 16(30)$

Witnessing acts of violence 44

(73)/ $42(79$, Treats $36(60) / 29$

(55) Harassment 27 (45)/ 33 (62)

$\begin{array}{lllllllll}\mathrm{Y} & \mathrm{Y} & \mathrm{N} & \mathrm{Y} & \mathrm{N} & \mathrm{Y} & \mathrm{Y} & \mathrm{Y}\end{array}$

$\begin{array}{lllllllll}\mathrm{Y} & \mathrm{N} & \mathrm{N} & \mathrm{N} & \mathrm{N} & \mathrm{Y} & \mathrm{Y} & \mathrm{N}\end{array}$

Close to death 95 (56) Assassination of family members or friends $\begin{array}{lllllllll}\mathrm{Y} & \mathrm{Y} & \mathrm{Y} & \mathrm{Y} & \mathrm{N} & \mathrm{Y} & \mathrm{N} & \mathrm{N}\end{array}$ 90 (53) Brainwashing 86 (51)

Witnessed or experienced events: Unnatural death of family or friend 32 (68) Being close to death 34 (64) Murder of family or friend $32(60)$ 


\section{Author \\ Country \\ Ethnicityl \\ nationality \\ Legal status \\ Date}

\section{Study design \\ Sampling meth- od Recruitment \\ context \\ Sample size $n$ \\ Response rate}

(\%)
Type of Included

measure/ participants $\mathbf{n}^{\mathbf{a}}$

Instrument-no. (F/M)

of items

\section{Torture n (\%) ${ }^{\mathbf{b}} \quad$ Witnessed}

torture n (\%)

\begin{tabular}{|c|c|c|c|c|}
\hline $\begin{array}{l}\text { Schweitzer, } \\
\text { Brough et al. (35) } \\
\text { Australia } \\
\text { Burmese } \\
\text { Refugees }\end{array}$ & $\begin{array}{l}\text { Cross-sectional } \\
\text { Consecutive } \\
\text { NGOs, commu- } \\
\text { nity } \\
75 \text { (93) }\end{array}$ & $\begin{array}{l}\text { Structured } \\
\text { interview } \\
\text { HTQ-16 }\end{array}$ & $70(40 / 30)$ & $20(30)$ \\
\hline $\begin{array}{l}\text { Schweitzer, } \\
\text { Melville et al. (65) } \\
\text { Australia } \\
\text { Sudanese } \\
\text { Refugees } \\
2003\end{array}$ & $\begin{array}{l}\text { Cross-sectional } \\
\text { Convenience } \\
\text { Community }\end{array}$ & $\begin{array}{l}\text { Structured } \\
\text { interview } \\
\text { HTQ-16 }\end{array}$ & $63(21 / 42)$ & $13(21)$ \\
\hline $\begin{array}{l}\text { Shannon et al. } \\
\text { (31) } \\
\text { USA } \\
\text { Karen } \\
\text { Refugees } \\
2003\end{array}$ & $\begin{array}{l}\text { Cross-sectional } \\
\text { Total } \\
\text { Health screen } \\
181(99)\end{array}$ & $\begin{array}{l}\text { Structured } \\
\text { interview }\end{array}$ & $179(87 / 92)$ & $49(27)$ \\
\hline $\begin{array}{l}\text { Silove et al. (38) } \\
\text { Australia } \\
\text { Tamil } \\
\text { Asylum seekers/ } \\
\text { Refugees }\end{array}$ & $\begin{array}{l}\text { Cross-sectional } \\
\text { Convenience } \\
\text { Community }\end{array}$ & $\begin{array}{l}\text { Self report } \\
\text { HTQ-16 }\end{array}$ & $\begin{array}{l}62(14 / 48) \\
/ 30\end{array}$ & $16(26) / 4(13)$ \\
\hline $\begin{array}{l}\text { Steel, Silove, } \\
\text { Brooks et al. (40) } \\
\text { Australia } \\
\text { Mandaean } \\
\text { TPV-holders/ } \\
\text { PPV-holders }\end{array}$ & $\begin{array}{l}\text { Cross-sectional } \\
\text { Convenience } \\
\text { Community } \\
268(90)\end{array}$ & $\begin{array}{l}\text { Self report } \\
\text { HTQ-15 }\end{array}$ & $\begin{array}{l}241 \\
(109 \\
/ 132)\end{array}$ & $37(15)$ \\
\hline $\begin{array}{l}\text { Steel, Silove, Phan } \\
\text { et al. (66) } \\
\text { Australia } \\
\text { Vietnamese } \\
\text { Refugees }\end{array}$ & $\begin{array}{l}\text { Cross-sectional } \\
\text { Random } \\
\text { Community } \\
1413(82)\end{array}$ & $\begin{array}{l}\text { Structured } \\
\text { interview } \\
\text { HTQ-24 }\end{array}$ & $1161(689 / 472)$ & $\begin{array}{l}10(1) \text { Torture, } \\
\text { victim of } \\
\text { terrorists }\end{array}$ \\
\hline $\begin{array}{l}\text { Sundquist and } \\
\text { Johansson (59) } \\
\text { Sweden } \\
\text { Latin American } \\
\text { Refugees } \\
1991\end{array}$ & $\begin{array}{l}\text { Cross-sectional } \\
\text { Total } \\
\text { Community } \\
413 \text { (83) }\end{array}$ & $\begin{array}{l}\text { Structured } \\
\text { interview }\end{array}$ & $\begin{array}{l}338 \\
(174 / 174)\end{array}$ & $78(23)$ \\
\hline
\end{tabular}




\section{Secondary \\ torture $\mathbf{n}(\%)^{\mathbf{b}}$ \\ Three most common}

traumas. Item, $\mathbf{n}(\%)$

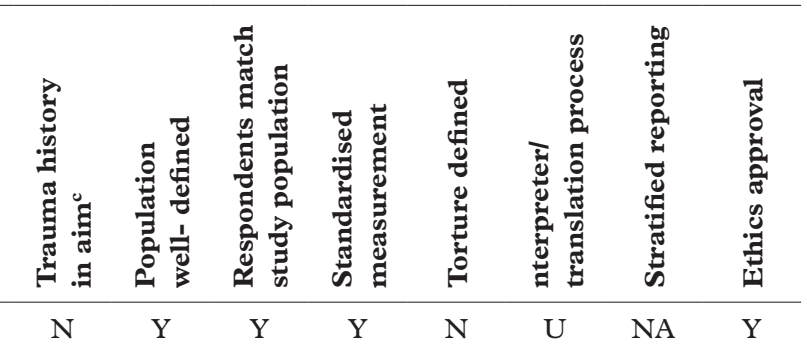

Combat situation 38 (58) Forced separation from family members 31 (46) Unnatural death of family or friend 29 (43)

$30(48)$

Forced separation from family

$92(51)$
$\begin{array}{llllllll}\mathrm{N} & \mathrm{Y} & \mathrm{N} & \mathrm{Y} & \mathrm{N} & \mathrm{U} & \mathrm{NA} & \mathrm{N}\end{array}$

(U)

25 (39) $\quad \begin{aligned} & \text { Combat situation } 38 \text { (58) Forced } \\ & \text { separation from family members } \\ & \\ & 31(46) \text { Unnatural death of family } \\ & \text { or friend } 29(43)\end{aligned}$
members $54(86)$ Murder of
family of friend 43 (68) Combat
members 54 (86) Murder of
family of friend 43 (68) Combat situation 24 (38) situation $24(38)$

War trauma $154(86)$

$\begin{array}{lllllllll}\text { Y } & \text { Y } & \text { Y } & \text { Y } & \text { Y } & \text { Y } & \text { Y } & \text { N }\end{array}$

Unnatural death of family or friend 29 (47)/ 16 (53) Forced $\begin{array}{lllllllll}\mathrm{Y} & \mathrm{Y} & \mathrm{N} & \mathrm{Y} & \mathrm{N} & \mathrm{Y} & \mathrm{Y} & \mathrm{N}\end{array}$ separation from family members 29 (46)/ 14 (47) Murder of stranger or strangers 29 (46)/ 12 (40)

Unnatural death of family or friend 110 (79)/ 63 (62) Being close to death 106 (76)/ 29 (29) Murder of family or friend 105 (75)/ 62 (61)

Being close to death 167 (14) Imprisonment 146 (13) Forced $\begin{array}{lllllllll}\mathrm{N} & \mathrm{Y} & \mathrm{Y} & \mathrm{Y} & \mathrm{N} & \mathrm{Y} & \mathrm{NA} & \mathrm{Y}\end{array}$ 129 (11) 


\begin{tabular}{|c|c|c|c|c|c|}
\hline $\begin{array}{l}\text { Author } \\
\text { Country } \\
\text { Ethnicity/ } \\
\text { nationality } \\
\text { Legal status } \\
\text { Date }\end{array}$ & $\begin{array}{l}\text { Study design } \\
\text { Sampling meth- } \\
\text { od Recruitment } \\
\text { context } \\
\text { Sample size } n \\
\text { Response rate } \\
(\%)\end{array}$ & $\begin{array}{l}\text { Type of } \\
\text { measurel } \\
\text { Instrument-no. } \\
\text { of items }\end{array}$ & $\begin{array}{l}\text { Included } \\
\text { participants } \mathbf{n}^{\mathrm{a}} \\
(\mathrm{F} / \mathrm{M})\end{array}$ & Torture n $(\%)^{b}$ & $\begin{array}{l}\text { Witnessed } \\
\text { torture } \mathbf{n}(\%)^{\mathbf{b}}\end{array}$ \\
\hline $\begin{array}{l}\text { Taloyan et al. (46) } \\
\text { Sweden } \\
\text { Kurdish } \\
\text { Refugees } \\
\text { /Immigrants } \\
1991\end{array}$ & $\begin{array}{l}\text { Cross-sectional } \\
\text { Random } \\
\text { Community } \\
299(66)\end{array}$ & $\begin{array}{l}\text { Structured } \\
\text { interview }\end{array}$ & $\begin{array}{l}197 \\
(86 / 111)\end{array}$ & & \\
\hline $\begin{array}{l}\text { Turner et al. (54) } \\
\text { UK } \\
\text { Kosovo-Albanian } \\
\text { Refugees } \\
1999-2000\end{array}$ & $\begin{array}{l}\text { Cross-sectional } \\
\text { Consecutive } \\
\text { Community }\end{array}$ & $\begin{array}{l}\text { Self report } \\
\text { WTQ-14 }\end{array}$ & $\begin{array}{l}842 \\
(445 / 397)\end{array}$ & & \\
\hline $\begin{array}{l}\text { Willard et al. (24) } \\
\text { USA } \\
\text { Iraqi } \\
\text { Refugees } \\
2008-2009\end{array}$ & $\begin{array}{l}\text { Cross-sectional } \\
\text { Consecutive } \\
\text { Health screen } \\
511(97)\end{array}$ & $\begin{array}{l}\text { Records of } \\
\text { interviews }\end{array}$ & $306(129 / 177)$ & $111(36)$ & \\
\hline
\end{tabular}




\section{Secondary Three most common}

torture $\mathbf{n}(\%)^{\mathrm{b}} \quad$ traumas. Item, $\mathbf{n}(\%)$

$\begin{array}{lllllllll}\mathrm{N} & \mathrm{Y} & \mathrm{N} & \mathrm{N} & \mathrm{NA} & \mathrm{Y} & \mathrm{NA} & \mathrm{N}\end{array}$

Shelling at close range 754 (91)

Shooting at close range 747 (90) 


\section{Appendix B}

\section{Critical appraisal checklist for studies reporting prevalence of torture and war related PTEs in refugees}

Reviewer:

Date:

Author:

Record no:

Yes No Unclear Not

Is trauma history part of the outcome of the study?

applicable

(If trauma history is not part of the outcome of the study, only the Sampling, Measurement and Ethics

items should be considered, not Analysis)

\section{Sampling}

1 . Is the target population defined clearly?

2. Was probability sampling used to identify potential respondents?

3. Do the characteristics of respondents match the target population?

\section{Measurement}

4. Are the data collection methods standardised?

5. Are the survey instruments reliable?

6. Are the survey instruments valid for the study group?

7. Is torture properly defined, and responses checked against that definition (if applicable)?

8. Are appropriate translation standards (translation-back translation) met and/or trained interpreters used (if applicable)?

\section{Analysis}

9. Are trauma history results reported and analysed and for subgroups of the study group?

10. Do the reports include confidence intervals for statistical estimates?

\section{Ethics}

11. Is the study approved by an ethical committee or discusses ethical implications in a satisfactory way?

Comments: 


\section{Instructions:}

For studies where trauma history is not part of the reported outcome of the study, questions 9 and 10 (Analysis) are not applicable. For reporting appraisal in the excel table, use these abbreviations:

$$
\text { Yes }=\text { Y, } \quad \text { No=N, Unclear }=\mathrm{U}, \quad \text { Not Applicable }=\mathrm{NA}
$$

\section{Sampling}

1. Is the target population defined clearly? See Boyle 1998

2. Was probability sampling used to identify potential respondents?

See Boyle 1998. If mixed random/consecutive and non-random sampling is used, mark UNCLEAR in the checklist.

3. Do the characteristics of respondents match the target population?

See Boyle 1998

\section{Measurement}

4. Are the data collection methods standardised? See Boyle 1998.

5. Are the survey instruments reliable? See Boyle 1998.

6. Are the survey instruments valid for the study group? See Boyle 1998.

7. Is torture properly defined, and responses checked against that definition?

Do the researchers state what definition of torture is used? Have they made sure that what is reported by the respondents as torture meet that definition? This question is only applicable for studies where prevalence of "torture", "witnessing torture" and/or "secondary torture" are reported.

8. Are appropriate translation standards (translation-back translation) met and/or trained interpreters used (if applicable)?

Have the researchers used translation-back translation procedures when translating the instruments/questionnaires used (if applicable)? Do they use trained interpreters or bilingual interviewers in a satisfactory way when interviewing respondents (if applicable)?

\section{Analysis}

9. Are trauma history results reported and analysed and for subgroups of the study group? Have the researchers reported trauma history (torture, witnessing torture, secondary torture and/or other trauma history items) for subgroups (age groups, gender, origin etc.) of the sample?

10. Do the reports include confidence intervals for statistical estimates? See Boyle 1998.

\section{Ethics}

11. Is the study approved by an ethical committee and discusses ethical implications in a satisfactory way?

Both approval and satisfactory discussion of ethical implications should be present in order to answer this question with YES. 